\title{
Comparison of the Compositional, Microbiological, Biochemical, and Volatile Profile Characteristics of Nine Italian Ewes' Milk Cheeses
}

\author{
R. Coda, ${ }^{\star}$ E. Brechany,† M. De Angelis, ${ }^{\star 1}$ S. De Candia, ${ }^{\star}$ R. Di Cagno, ${ }^{\star}$ and M. Gobbetti* \\ ${ }^{*}$ Dipartimento di Protezione delle Piante e Microbiologia Applicata, Università degli Studi di Bari, Bari 70126, Italy \\ †Hannah Research Institute, Ayr, KA6 5HL Scotland
}

\begin{abstract}
Nine Italian ewes' milk cheeses were compared for compositional, microbiological, biochemical, and volatile profile characteristics. Mean values for the gross composition were rather similar among cheeses. The lowest $\mathrm{pH}$ values were found for cheeses that used primary starters. At the end of ripening, cheeses made from raw milk contained $>6.0 \log _{10} \mathrm{cfu} / \mathrm{g}$ of nonstarter lactic acid bacteria. Several species of lactobacilli were identified, but Lactobacillus plantarum and Lactobacillus paracasei were dominant. Random amplified polymorphic DNA-PCR analysis showed the biodiversity among the strains, and in several cases a relationship with the cheese of provenance. Cheeses differed mainly for secondary proteolysis, as shown by the principal component analysis applied to reversed-phase fast protein liquid chromatography data of the $\mathrm{pH} 4.6$-soluble fractions and by determination of the free AA. A total of 113 volatile components were identified in the Italian Pecorino cheeses by solid-phase microextraction coupled with gas chromatography-mass spectrometry analysis. The volatile profiles of the 9 cheeses differed significantly. Quantitatively, alcohols were the most abundant chemical class for some cheeses, whereas ketones were the most abundant for other cheeses. Esters and carboxylic acids were largely found. Specific volatile components seemed to distinguish specific cheeses.
\end{abstract} Key words: Pecorino cheese, nonstarter lactic acid bacteria, proteolysis, volatile component

\section{INTRODUCTION}

Cheese is considered the most diverse group of dairy products. Italy is one of the countries in the world with the largest and most diverse production of cheeses made from cows', ewes', goats', and buffalos' milks. "Pecorino" is the trivial name given to Italian cheeses made from ewes' milk. In 2004, the Italian production of cheeses

Received March 1, 2006.

Accepted May 25, 2006.

${ }^{1}$ Corresponding author: m.deangelis@agr.uniba.it made from ewes' milk was approximately $89,976 \mathrm{t}$. Beyond the production of well-known cheeses such as Pecorino Romano, Fiore Sardo, and Canestrato Pugliese (approximately 36,249 t), there is a large variety of Pecorino cheeses (approximately 53,727 t), mostly without a "designation of origin," which have typical characters and originate from a delimited geographical area (Largo Consumo, 2004; ISTAT, 2001). Pecorino del Tarantino, Pecorino Leccese (Apulia region, southern Italy), Pecorino di Filiano (Basilicata region, southern Italy), Pecorino del Reatino (Lazio region, central Italy), Pecorino Sardo (the only one with a "protected designation of origin," or PDO status; Sardinia region, southern Italy), Pecorino Umbro (Umbria region, central Italy), Pecorino di Pienza (Tuscany region, central Italy), Pecorino Marchigiano (Marche region, central Italy), and Pecorino Piemontese (Piedmont region, northern Italy) may be considered typical examples of Pecorino cheeses that are produced throughout the Italian territory. They are manufactured in industrial or mostly semi-industrial plants according to local or regional traditions, they have different national and international markets, and they are obtained by technologies that differ in part. Although particular cheeses may be consumed after different periods of ripening, the abovementioned cheeses belong to the semihard category, are manufactured by using raw milk (except for Pecorino Umbro and Pecorino di Pienza) and rennet paste (except for Pecorino di Pienza), and do not use primary natural or commercial starter cultures (except for Pecorino Sardo and Pecorino Umbro, respectively). As a consequence, adventitious microorganisms, represented mainly by nonstarter lactic acid bacteria (NSLAB) that derive from raw milk (Berthier et al., 2001) or from the dairy environment and surfaces of equipment used in cheese manufacture (Somers et al., 2001), play the most important role in cheese during ripening.

The most famous Italian PDO Pecorino cheeses, for example, Pecorino Romano (Battistotti and Corradini, 1993; Pirisi et al., 2000; Di Cagno et al., 2003), Fiore Sardo (Mannu et al., 2000; Larràyoz et al., 2001), and Canestrato Pugliese (Albenzio et al., 2001; Corbo et al., 2001), have been subjected to studies regarding proteolysis, lipolysis, microbiology, technology, volatile profile 
analysis, and sensory analysis. The same has been done for the most famous Spanish PDO cheeses made from ewes' milk such as Manchego (Martinez-Castro et al., 1991; Villasenor et al., 2000), Roncal (Izco and Torre, 2000; Ortigosa et al., 2001), Idiazabal (Pérez Elortondo et al., 1998), and Zamorano (Barron et al., 2004), and for Portuguese PDO cheeses, namely, Serra (Macedo et al., 2004) and Terrincho (Pinho et al., 2003a, 2004a,b). Nevertheless, no studies have been carried out on the Italian Pecorino cheeses mentioned, which deserve interest in terms of either market popularity or their typical features. Comparative studies based on microbiological, compositional, biochemical, and volatile profile characteristics of several cheeses belonging to the same variety may be helpful for 1) differentiating cheeses, 2) establishing the effect of selected technological parameters on specific differences in the microbial flora and related biochemical activities, and, in general, 3) finding the most appropriate characteristics suitable for obtaining a legal "designation of origin," which may increase the market popularity of individual cheeses.

Consequently, 2 major hypotheses should be investigated: 1) Pecorino cheeses produced in Italy could present differences in microbiological, compositional, biochemical, and volatile profile characteristics, and 2) an integrated characterization could define the major distinguishing traits of Italian Pecorino cheeses. In this study, the microbiological, compositional, biochemical, and volatile profile characteristics of the 9 Italian Pecorino cheeses mentioned were compared.

\section{MATERIALS AND METHODS}

\section{Cheese Samples}

Nine Italian Pecorino cheeses were considered in this study: Pecorino del Tarantino, Pecorino Leccese, Pecorino di Filiano, Pecorino del Reatino, Pecorino Sardo, Pecorino Umbro, Pecorino di Pienza, Pecorino Marchigiano, and Pecorino Piemontese. The manufacturing protocols are shown in Figure 1. Cheeses were supplied in triplicate (different batches) by local cheese markets and were stored at $4^{\circ} \mathrm{C}$ for a few hours before analyses. All the analyses were carried out at least in duplicate for each batch of cheese (a total of 6 analyses).

\section{Enumeration and Isolation of NSLAB}

Samples ( $20 \mathrm{~g}$ ) of cheeses were diluted in $180 \mathrm{~mL}$ of a sodium citrate $(2 \% \mathrm{wt} / \mathrm{vol})$ solution and homogenized with a Stomacher Lab-Blender 400 (PBI International, Milan, Italy). Serial dilution were made in quarterstrength Ringer's solution and plated on de Man, Rogosa, and Sharpe (MRS) agar (Oxoid Ltd., Basingstoke, Hampshire, UK) for viable counts. Mesophilic lactoba- cilli were enumerated after incubation at $30^{\circ} \mathrm{C}$ for 48 to $72 \mathrm{~h}$.

At least 10 colonies, possibly with different morphologies, were isolated from the last plate dilution. Grampositive, catalase-negative, nonmotile rod isolates were cultivated in MRS broth (Oxoid Ltd.) at $30^{\circ} \mathrm{C}$ for $24 \mathrm{~h}$, and restreaked onto MRS agar. All the isolates considered for further analyses showed the capacity of acidifying the culture medium and grew at $15^{\circ} \mathrm{C}$ but not at $45^{\circ} \mathrm{C}$. Mesophilic microbial cultures were stored at $-20^{\circ} \mathrm{C}$ in $10 \%$ (vol/vol) glycerol.

\section{Random Amplified Polymorphic DNA-PCR Analysis}

Genomic DNA were extracted as reported by De Los Reyes-Gavilán et al. (1992), from $2 \mathrm{~mL}$ of overnight cultures grown in MRS at $30^{\circ} \mathrm{C}$. Three primers (Invitrogen Life Technologies, Milan, Italy), with arbitrarily chosen sequences (P4, 5'-CCGCAGCGTT-3'; P7, 5'-AGCAGCGTGG-3'; and M13, 5'-GAGGGTGGCGGT TCT-3'; De Angelis et al., 2001; Rossetti and Giraffa, 2005) were used singly in 3 series of amplification. The reaction mixture contained $200 \mu M$ of each 2 -deoxynucleoside $5^{\prime}$-triphosphate, 1 to $2 \mu M$ primer, 1.5 to 3 $\mu M \mathrm{MgCl}_{2}, 1.25 \mathrm{U}$ of Taq DNA polymerase (Invitrogen), $2.5 \mu \mathrm{L}$ of PCR buffer, $25 \mathrm{ng}$ of DNA, and sterile doubledistilled water to $25 \mu \mathrm{L}$. For amplifications with primers $\mathrm{P} 4$ and $\mathrm{P} 7$, the PCR program comprised 45 cycles of denaturation for $1 \mathrm{~min}$ at $94^{\circ} \mathrm{C}$, annealing for $1 \mathrm{~min}$ at $35^{\circ} \mathrm{C}$, and elongation for $2 \mathrm{~min}$ at $72^{\circ} \mathrm{C}$; the cycles were preceded by denaturation at $94^{\circ} \mathrm{C}$ for $4 \mathrm{~min}$ and followed by elongation at $72^{\circ} \mathrm{C}$ for $5 \mathrm{~min}$. For primer M13, amplification reactions were performed according to the protocol described by Giraffa et al. (2000): one cycle at $94^{\circ} \mathrm{C}$ for $60 \mathrm{~s}$ (denaturing), $42^{\circ} \mathrm{C}$ for $20 \mathrm{~s}$ (annealing), and $72^{\circ} \mathrm{C}$ for $2 \mathrm{~min}$ (elongation). Polymerase chain reaction products were separated by electrophoresis (2 $\mathrm{h}$ at $130 \mathrm{~V}$ ) on $1.5 \%$ (wt/vol) agarose gel (Invitrogen), and the DNA was detected by UV transillumination after staining with ethidium bromide $(0.5 \mu \mathrm{g} / \mathrm{mL})$. The molecular weight of the amplified DNA fragments was estimated by comparison with a $1 \mathrm{~Kb}$ Plus DNA Ladder (Invitrogen) ranging from 100 to $12,000 \mathrm{bp}$. For random amplified polymorphic DNA (RAPD) markers, the presence or absence of fragments was recorded as 1 or 0 , respectively. Only reproducible well-marked amplified fragments were scored, with faint bands being ignored. Two series of RAPD-PCR profiles were combined to obtain a unique dendrogram. Pairwise comparison of banding patterns was evaluated, with an index of genetic similarity calculated using the simple matching coefficient (Sokal and Michener, 1958). 


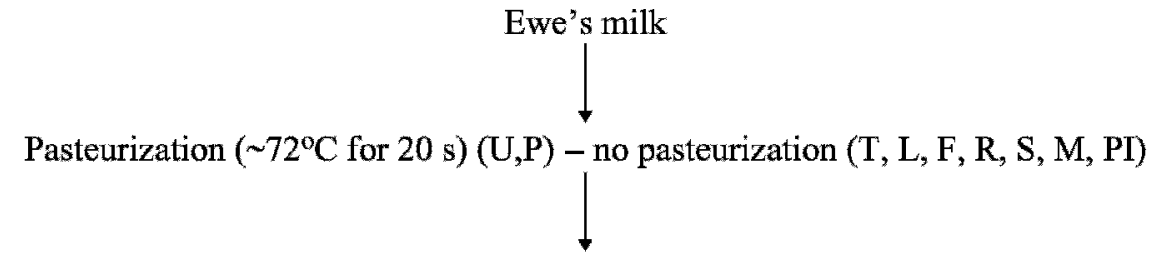

Heating (T, L, F, R, S, M, PI) or cooling (U, P) of milk to $38-40^{\circ} \mathrm{C}$ )

Inoculum of the milk with natural starters ("scotta fermento," Lactobacillus helveticus, Lactobacillus delbrueckii subsp. bulgaricus, and Streptococcus thermophilus) (S) or commercial starters (Lactococcus lactis subsp. lactis, Lactococcus lactis subsp. cremoris, Lb. delbrueckii subsp. bulgaricus, and Str. thermophilus) (U) at $\sim 7.0 \log _{10} \mathrm{cfu} / \mathrm{mL}$ - no inoculum with starters ( T, L, F, R, P, M, PI)

Milk held at $38-40^{\circ} \mathrm{C}$ for $30 \mathrm{~min}$ (all cheeses)

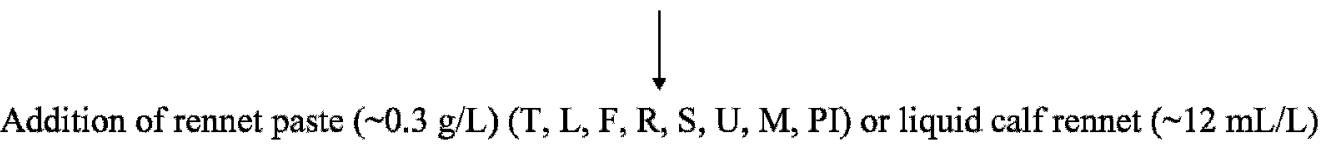

(P)<smiles>CCOC</smiles>

Coagulation of milk at $30-35^{\circ} \mathrm{C}$ after $\sim 30$ min (all cheeses)

Cutting of coagulum (size of the curd after cutting: $\sim 0.5-1.5 \mathrm{~cm}$ ) (all cheeses)

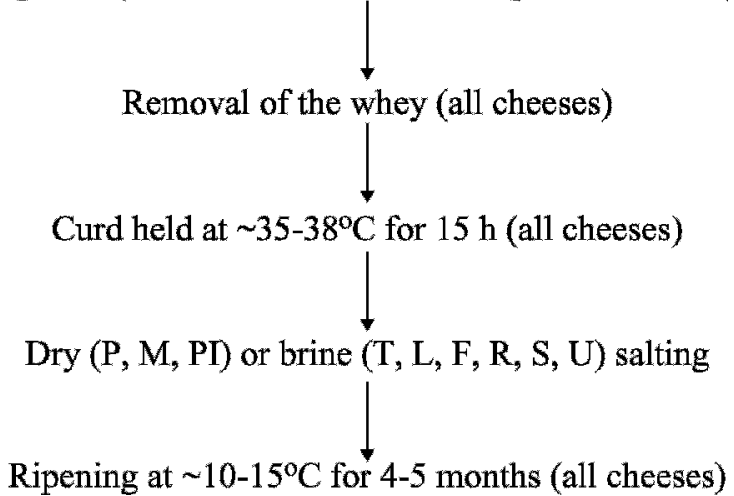

Figure 1. Protocols for the manufacture of the 9 Italian Pecorino cheeses. T, Pecorino del Tarantino; L, Pecorino Leccese; F, Pecorino di Filiano; R, Pecorino del Reatino; S, Pecorino Sardo; U, Pecorino Umbro; P, Pecorino di Pienza; M, Pecorino Marchigiano; PI, Pecorino Piemontese.

\section{Genotypic Identification by 165 rRNA Gene Sequence Analysis}

Genomic DNA from each strain was extracted as reported above. Two primer pairs (Invitrogen), LacbF/ LacbR and LpCoF/LpCoR (De Angelis et al., 2006), were used to amplify the 16S rRNA gene fragment of lactobacilli. Fifty microliters of each PCR mixture contained
$200 \mu M$ of each 2 '-deoxynucleoside 5 '-triphosphate, 1

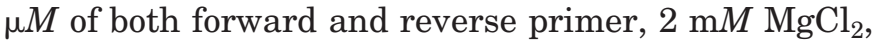
$2 \mathrm{U}$ of $T a q$ DNA polymerase (Invitrogen) in the supplied buffer, and approximately $50 \mathrm{ng}$ of DNA. The expected amplicons of about 1,400 and 1,000 bp (after amplification with the primers pairs LacbF/LacbR and $\mathrm{LpCoF} /$ LpCoR, respectively) were eluted from gel and purified by the GFX PCR DNA and Gel Band Purification Kit 
(Amersham Biosciences, Piscataway, NJ). Taxonomic strain identification was performed by comparing the sequences of each isolate with those reported in the Basic BLAST database (Altschul et al., 1997). Strains showing homology of at least $97 \%$ were considered to belong to the same species (Goebel and Stackebrandt, 1994).

\section{Compositional Analysis}

Moisture, $\mathrm{NaCl}$, and $\mathrm{pH}$ were determined as reported by the International Dairy Federation (IDF 1970, 1988, 1989). Protein and fat were determined by the microKjeldahl method (IDF, 1964) and Soxhlet method using diethyl ether (Gobbetti et al., 1999), respectively. All determinations were carried out on 3 different sections of each cheese and values were averaged.

\section{Assessment of Proteolysis}

The $\mathrm{pH}$ 4.6-insoluble and -soluble fractions of the cheeses were obtained as described by Kuchroo and Fox (1982). All fractions of the cheeses were analyzed by urea-PAGE, using an SE 600 electrophoresis unit (Hoefer, Amersham Biosciences) and the stacking gel system described by Andrews (1983). The gels were stained directly by the method of Blakesley and Boezi (1977) with Coomassie brilliant blue G250.

The peptide profiles of the $\mathrm{pH} 4.6$-soluble fractions were determined by reversed-phase fast-protein liquid chromatography (RP-FPLC) using a Resource RPC column and ÄKTA FPLC equipment with a UV detector operating at $214 \mathrm{~nm}$ (Amersham Biosciences). For each cheese, aliquots $(1 \mathrm{~mL})$ of the $\mathrm{pH} 4.6$-soluble extracts, containing 1.5 to $3 \mathrm{mg}$ of peptides as determined by the $o$-phthaldialdehyde method (Church et al., 1983), were added to $0.05 \%$ (vol/vol) trifluoroacetic acid, and centrifuged at $10,000 \times g$ for $10 \mathrm{~min}$. The supernatant was filtered through a Millex-HA $0.22-\mu \mathrm{m}$ pore size filter (Millex-HA, Millipore S.A., Saint Quentin, France) and loaded onto the column. Gradient elution was performed at a flow rate of $1 \mathrm{~mL} / \mathrm{min}$ using a mobile phase composed of water and acetonitrile containing $0.05 \%$ trifluoroacetic acid. The $\mathrm{CH}_{3} \mathrm{CN}$ content was increased linearly from 5 to $46 \%$ between 16 and $62 \mathrm{~min}$, and from 46 to $100 \%$ between 62 and $72 \mathrm{~min}$. Total and individual free $\mathrm{AA}$ of the $\mathrm{pH} 4.6$-soluble fraction were analyzed by a Biochrom 30 series Amino Acid Analyzer (Biochrom Ltd., Cambridge Science Park, UK) with a $\mathrm{Na}$ - cation-exchange column $(20 \times 0.46 \mathrm{~cm}$ i.d. $)$. A mixture of AA of known concentration (Sigma Chemical Co., St. Louis, MO) was added to cysteic acid, methionine sulfoxide, methionine sulfone, Trp, and Orn, and used as the standard. Proteins and peptides in the samples were precipitated by addition of $5 \%$ (vol $/ \mathrm{vol}$ ) cold solid sulfosalicylic acid, holding at $4^{\circ} \mathrm{C}$ for $1 \mathrm{~h}$, and centrifuging at $15,000 \times g$ for $15 \mathrm{~min}$. The supernatant was filtered through a $0.22-\mu \mathrm{m}$ pore size filter and diluted, when necessary, with sodium citrate $(0.2 \mathrm{M}, \mathrm{pH} 2.2)$ loading buffer. Amino acids were postcolumn derivatized with ninhydrin reagent and detected by absorbance at 440 (Pro and hydroxyproline) or $570 \mathrm{~nm}$ (all other AA).

\section{Determination of Volatile Components}

The determination of volatile components was performed by solid-phase microextraction coupled with gas chromatography-mass spectrometry (SPME-GC-MS). Prior to analysis, cheese samples were sliced, frozen in liquid nitrogen, and then pulverized into small granules and stored at $-20^{\circ} \mathrm{C}$. Three grams of each cheese was then placed in a $15-\mathrm{mL}$ vial and allowed to equilibrate at $40^{\circ} \mathrm{C}$ for $30 \mathrm{~min}$. Extraction of the volatiles was carried out by injecting a carboxen-polydimethylsiloxane fiber into the vial and exposing it to the headspace for $30 \mathrm{~min}$ at $40^{\circ} \mathrm{C}$. Samples were desorbed onto an Agilent FFAP column, $50 \mathrm{~m} \times 0.2 \mathrm{~mm} \times 0.33 \mu \mathrm{m}$ (Agilent Technologies, Inc., Milan, Italy). The oven was held at $40^{\circ} \mathrm{C}$ for $2 \mathrm{~min}$, then increased at $5^{\circ} \mathrm{C}$ per minute to $70^{\circ} \mathrm{C}$, where it was held for $2 \mathrm{~min}$. The temperature was then increased at $10^{\circ} \mathrm{C}$ per minute to $240^{\circ} \mathrm{C}$ and held to give a run time of $35 \mathrm{~min}$. The mass spectrometer was set to record 33 to $450 \mathrm{amu}$ (threshold 1,000) at a sampling rate of 1.11 scans per second. The components were identified and a database was set up to quantify relative amounts of each. The database was constructed using selected ion monitoring as the parameter to determine the amount of each component. The data from the custom report were transferred into Excel (Microsoft Excel, 2003). The data are in the form $\left(\right.$ area $\times \mathrm{e}^{5}$ ) and are normalized to a weight of $1 \mathrm{~g}$ of sample. An ANOVA of the area transformed data was carried out using Minitab (Minitab Ltd., Brandon Court, UK) on the basis of cheese type and group.

\section{Statistical Analysis}

Data from microbiological and physicochemical analyses were subjected to one-way ANOVA (SAS Institute, 1985 and pairwise comparison of treatment means was achieved by Tukey's procedure at $P<0.05$, using the statistical software Statistica for Windows (Statistica 6.0 per Windows 1998; StatSoft Italia srl, Padova, Italy). Cluster analysis was conducted on similarity estimates using the unweighted pair group method with arithmetic average, from which a dendrogram representing the relationship between isolates was obtained. 
Analysis was performed using the statistical software Statistica for Windows (Statistica 6.0 per Windows 1998; StatSoft Italia srl). Peptide profiles of the $\mathrm{pH} 4.6$ soluble fractions of the cheeses were analyzed by using multivariate statistical techniques. Data for the factor reduction analysis were obtained by visually recognizing the peaks and taking peak heights as variables. Factor reduction analysis was performed on the data by the covariance matrix for the determination of principal components (PC; Pripp et al., 1999) using the statistical software Statistica for Windows (Statistica 6.0 per Windows 1998; StatSoft Italia srl).

\section{RESULTS}

\section{Compositional Analysis}

All Pecorino cheeses had moisture values ranging from 35.0 to $38.2 \%$ (wt/wt) and were considered as semihard cheeses (Table 1). Range values for fat and protein were 27.5 to 29.7 , and 26.4 to $27.7 \%$ (wt/wt), respectively. These values were in agreement with those recommended by the manufacturers or indicated in the guidelines for cheese manufacture. Large differences were found regarding the $\mathrm{pH}$ values 4.68 to 5.80 . In particular, Pecorino Sardo and Pecorino Umbro cheeses were characterized by the lowest values, $\mathrm{pH} 4.68$ and 5.05 , respectively. The $\mathrm{NaCl}$ content was rather uniform in all the cheeses and ranged from 1.5 to $2.3 \%$ (wt/wt). No particular differences were found for dry or brine-salted cheeses.

\section{Enumeration and Identification of NSLAB}

Cell numbers of presumptive mesophilic lactobacilli at the end of ripening varied from 3.2 to $8.27 \log _{10} \mathrm{cfu} /$ $\mathrm{g}$ (Figure 2). The lowest values were found for Pecorino Umbro and Pecorino di Pienza (3.2 and $5.28 \log _{10} \mathrm{cfu} /$ $\mathrm{g}$, respectively), whereas the other cheeses always had values higher than $6 \log _{10} \mathrm{cfu} / \mathrm{g}$.

Gram-positive, catalase-negative, nonmotile rods, growing at $15^{\circ} \mathrm{C}$ and acidifying, were isolated from the last plate dilution and subjected to preliminary RAPDPCR analysis by using single primers P4, P7, or M13. Primers M13 and P7 generated zero or a low number of bands for most of the isolates. For this reason, cluster analyses were performed by using RAPD-PCR profiles obtained with P4 and P7, and P4 and M13 (Figure 3, panels A and B, respectively). All isolates were further identified by partial sequencing of the $16 \mathrm{~S}$ rRNA. The following species were identified for each Pecorino cheese: Pecorino del Tarantino, Lactobacillus plantarum, Lactobacillus casei, and Lactobacillus brevis; Pecorino Leccese, Lb. plantarum and Lactobacillus paracasei; Pecorino di Filiano, Lb. plantarum and Lb. para- 


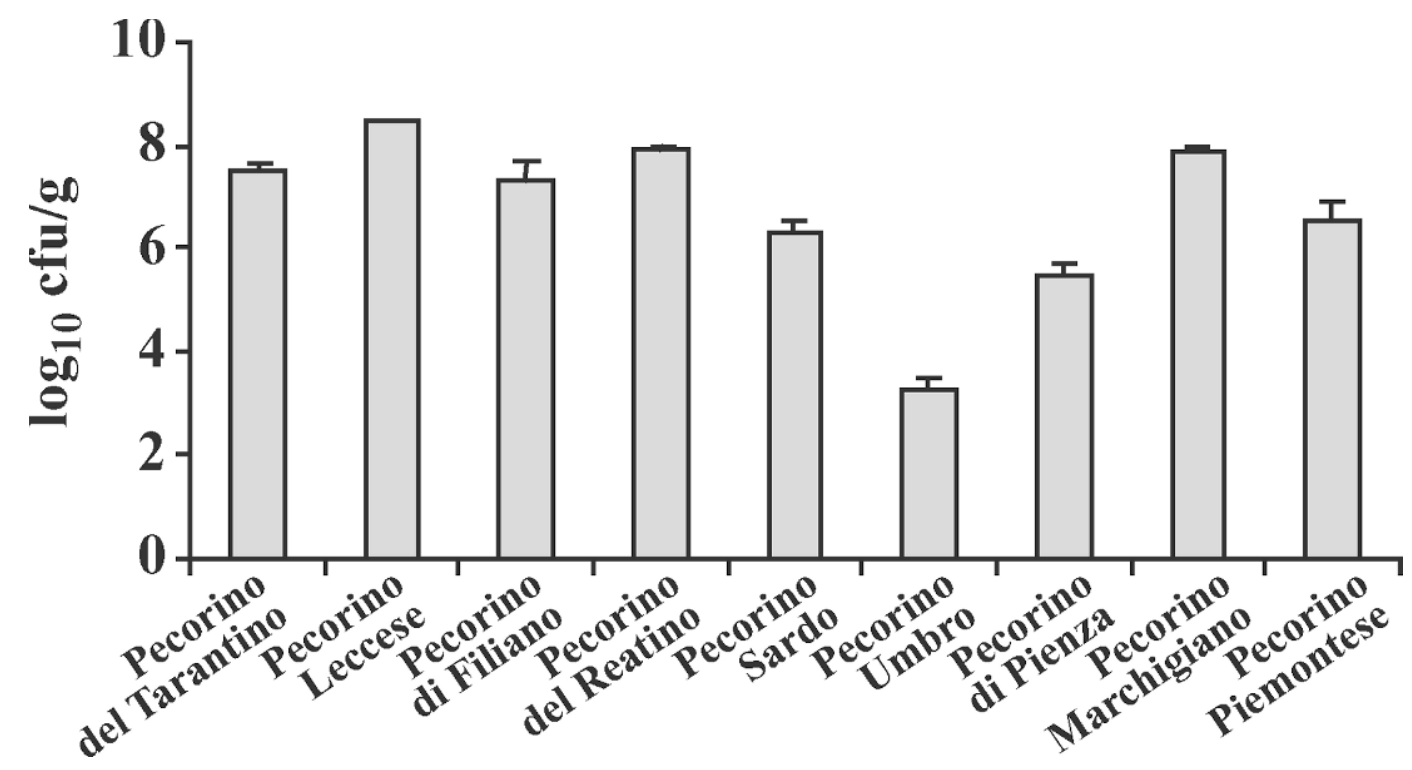

Figure 2. Cell numbers $\left(\log _{10} \mathrm{cfu} / \mathrm{g}\right)$ of presumptive mesophilic lactobacilli found in the 9 Italian Pecorino cheeses at the end of ripening. Data are the mean of 3 batches of each type of cheese, analyzed in duplicate, and standard deviations are reported.

casei; Pecorino del Reatino, Lb. plantarum and Lb. paracasei; Pecorino Sardo, Lb. plantarum and Lb. paracasei; Pecorino Umbro, Lb. plantarum and Lb. paracasei; Pecorino di Pienza, Lb. brevis; Pecorino Marchigiano, $L b$. plantarum and Lb. brevis; and Pecorino Piemontese, Lb. plantarum. Overall, $L b$. plantarum and $L b$. paracase $i$ were the species found most frequently, with 56 and 29 isolates over the total of 99 isolates. In most cases, strains of the same species did not group in a unique cluster but were separated into different clusters, depending mainly on the cheese. For instance, Lb. plantarum strains analyzed by primers $\mathrm{P} 4$ and $\mathrm{P} 7$ (Figure 3, panel A) were separated into 4 clusters at a similarity level of $80 \%$, in which cluster $\mathrm{C}$ isolates were from Pecorino di Filiano only, and cluster $\mathrm{G}$ and $\mathrm{H}$ isolates were from Pecorino del Tarantino only. The same was found (Figure 3, panel B) for clusters C and $\mathrm{D}$, with $L b$. plantarum strains isolated only from Pecorino del Reatino and Pecorino Sardo, respectively.

\section{Proteolysis}

The level of $\mathrm{pH} 4.6$-soluble nitrogen, expressed as the percentage of total nitrogen in cheese, was in the range of 18.4 to $25.0 \%$ (Table 1 ). The highest values $(>22.5 \%)$ were found in the order of Pecorino Piemontese $>$ Pecorino del Reatino > Pecorino Sardo > Pecorino Umbro > Pecorino di Filiano. Urea-PAGE of the $\mathrm{pH}$ 4.6-insoluble fractions (Figure 4) showed that $\alpha_{\mathrm{s} 1}-\mathrm{CN}$ was completely degraded in almost all the cheeses. $\beta$-Casein persisted at the end of ripening and formation of $\gamma$-CN was evi- dent, indicating plasmin activity. The urea-PAGE electrophoretograph of the $\mathrm{pH}$ 4.6-soluble fractions showed some differences among the cheeses. In particular, Pecorino del Tarantino, Pecorino di Filiano, Pecorino Sardo, and Pecorino Piemontese had characteristic protein bands (data not shown). The $\mathrm{pH} 4.6$-soluble fractions were also analyzed by RP-FPLC (Figure 5). For each of the 9 different RP-FPLC chromatograms, 35 peaks were recognized and matched visually with the Unicorn program (Amersham Biosciences). Quantitative, and especially qualitative, differences were evident for several cheeses. In particular, Pecorino del Tarantino, Pecorino di Filiano, Pecorino di Pienza, and Pecorino Marchigiano were characterized by various peptide peaks distributed throughout the acetonitrile gradient (Figure 5). Principal component analysis (PCA) was applied to RP-FPLC data. The score plot and loading plot of the first and second PC after PCA, based on 35 variables (peaks) of 9 Italian Pecorino cheeses, are shown in Figure 6 (panels A and B). The 2 PC explained $64.17 \%$ of the total variance. Pecorino del Reatino, Pecorino Sardo, and Pecorino Piemontese, characterized by the lowest peptide concentrations, were grouped together, whereas the other 6 cheeses occupied separate zones of the plane. The highest concentration of free AA was found for Pecorino Piemontese (51.12 mg/g), followed by Pecorino del Reatino (37.15 $\mathrm{mg} / \mathrm{g})$, Pecorino Sardo (31.00 mg/g), and Pecorino di Filiano (26.43 mg/g; Table 2). Overall, the AA found at the highest concentrations in all the cheeses were Asp, 
A

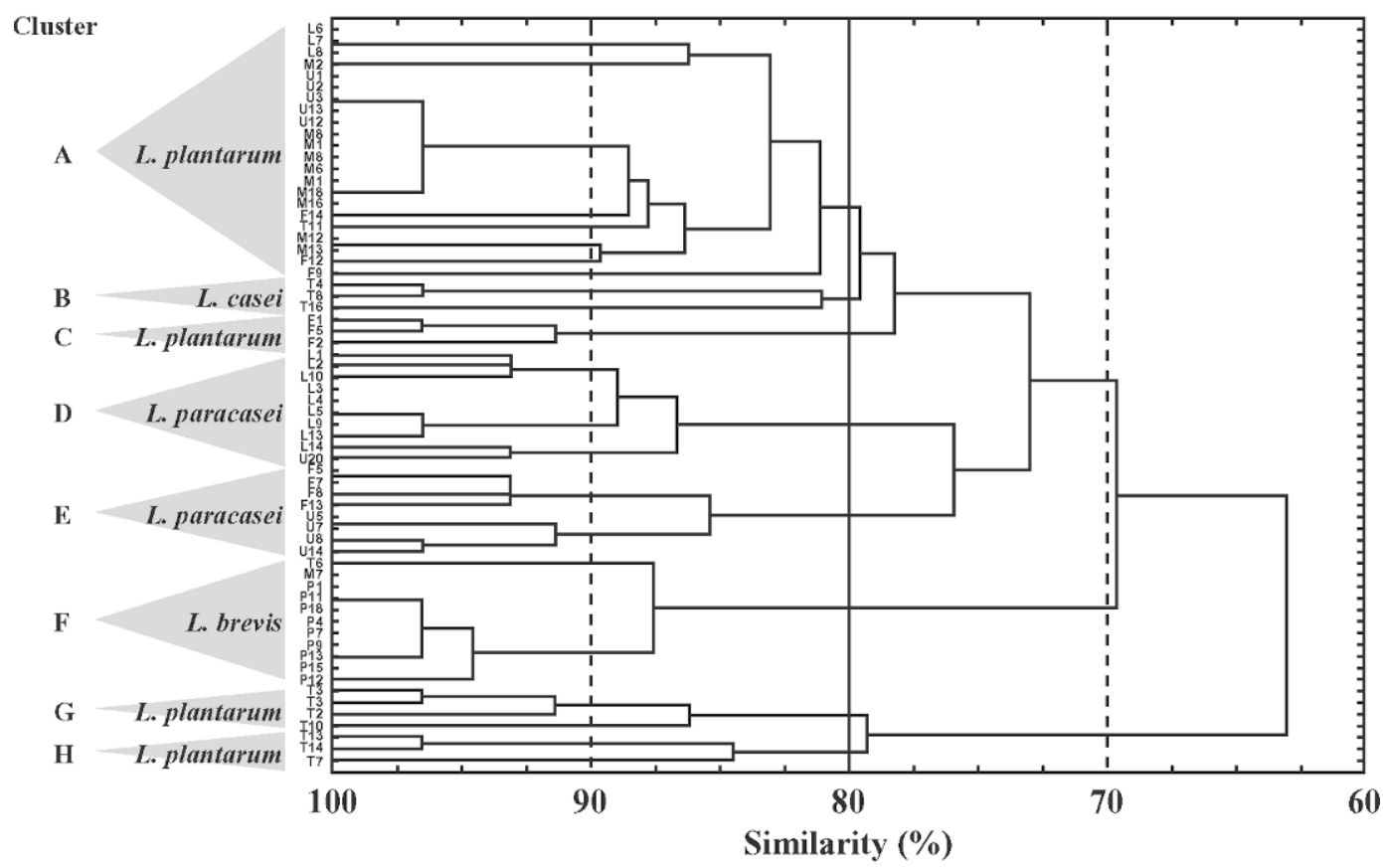

B

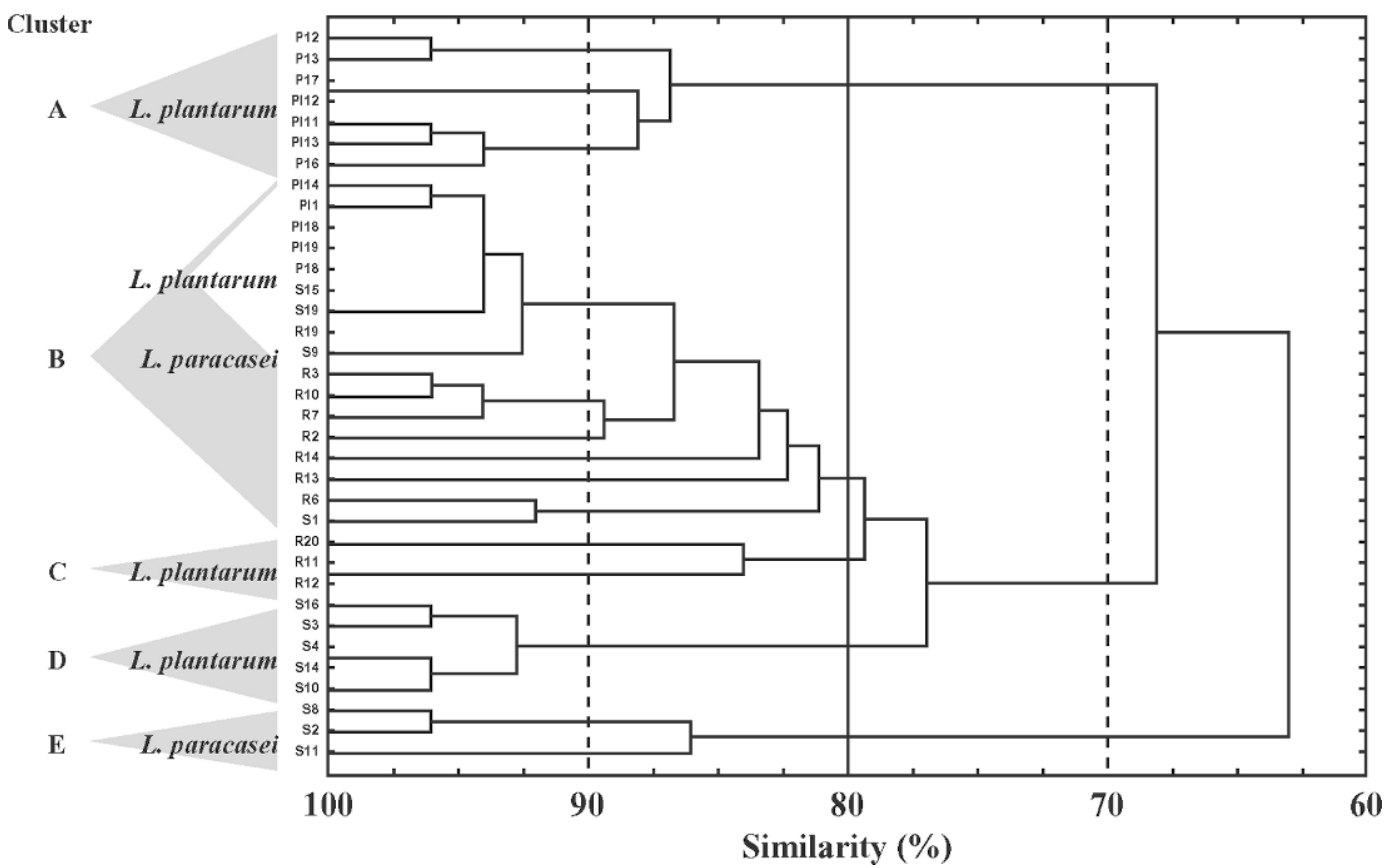

Figure 3. Dendrogram obtained by combined random amplification of polymorphic DNA patterns for the isolates from Pecorino cheeses using primer P4 and P7 (A), and P4 and M13 (B). Isolates were numbered based on cheese variety: T, Pecorino del Tarantino; L, Pecorino Leccese; F, Pecorino di Filiano; U, Pecorino Umbro; P, Pecorino di Pienza; M, Pecorino Marchigiano (A); R, Pecorino del Reatino; S, Pecorino Sardo; PI, Pecorino Piemontese (B). Cluster analysis was based on the simple matching coefficient and unweighted pair grouped method with arithmetic average.

Glu, Pro, Ile, Leu, Phe, and Lys. In particular, Pecorino del Reatino and Pecorino di Pienza showed, respectively, Thr and His at the highest concentrations, and
Pecorino di Filiano and Pecorino Piemontese were characterized by very elevated concentrations of Asp and Glu, respectively. 


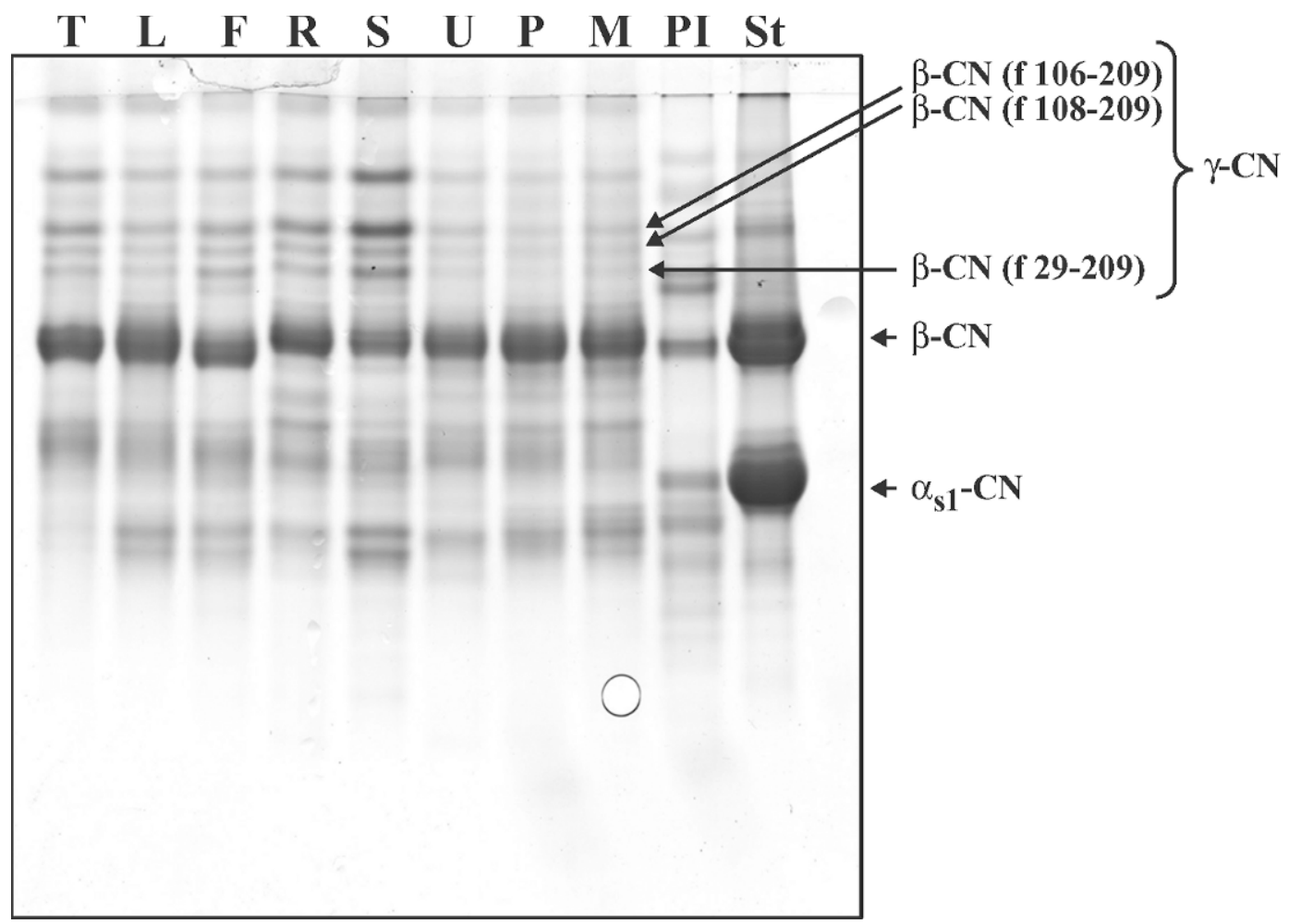

Figure 4. Urea-PAGE of the $\mathrm{pH}$ 4.6-insoluble fractions of the 9 Italian Pecorino cheeses at the end of ripening. Lanes: T, Pecorino del Tarantino; L, Pecorino Leccese; F, Pecorino di Filiano; R, Pecorino del Reatino; S, Pecorino Sardo; U, Pecorino Umbro; P, Pecorino di Pienza; M, Pecorino Marchigiano; PI, Pecorino Piemontese; St, ewes' milk CN.

\section{Volatile Components}

A total of 113 volatile components were identified in the Italian Pecorino cheeses and grouped according to chemical classes (Table 3). In most cases, the variability of the volatile components among the 3 batches of each type was not significant $(P>0.05)$. In contrast, except for 18 components, all the volatiles identified differentiated the cheeses with various degrees of statistical significance.

The largest amounts of total esters were found in Pecorino Marchigiano, Pecorino Piemontese, Pecorino Sardo, and Pecorino Leccese (Table 3). Pecorino del Reatino and Pecorino di Pienza contained one-fourth the amount or less of the esters found in the other cheeses. Butyl, propyl, and especially ethyl esters (ethyl acetate, ethyl butanoate, and ethyl hexanoate) were those characterizing the cheeses. The 3 ethyl-methyl esters identified were characteristic of Pecorino del Tarantino and Pecorino Leccese, which are manufactured in the same region (the Apulia region of southern Italy).

Except in Pecorino Leccese, Pecorino Marchigiano, and Pecorino Piemontese, ketones were the volatile components found at the highest levels (Table 3). 2-Alkanones with odd numbers of carbon atoms were found at the highest levels, showing quantitative differences among the cheeses. In particular, 2-propanone in Pecorino di Pienza; 2-pentanone in Pecorino di Pienza, Pecorino del Reatino, and Pecorino Leccese; and 2-heptanone in Pecorino di Pienza, Pecorino del Reatino, Pecorino Leccese, and Pecorino Sardo were those characterizing the cheeses. In contrast, 2-butanone was found mainly in Pecorino Marchigiano and Pecorino del Tarantino. 3-Hydroxy-2-butanone was found at the highest levels in cheeses (Pecorino del Tarantino and Pecorino di Pienza) in which diacetyl (2,3-butanedione) was also determined at the highest concentration.

Quantitatively, alcohols were the most abundant chemical class of volatiles in Pecorino Marchigiano, Pecorino Leccese, and Pecorino Piemontese (Table 3). Large amounts of ethanol were contained in all the cheeses, especially in these 3. Primary alcohols such as 1-butanol (especially in Pecorino di Filiano and Pecorino Sardo); secondary alcohols such as 2-butanol (especially in Pecorino Marchigiano, Pecorino Sardo, and Pecorino del Tarantino), 2-pentanol (especially in Pecorino Leccese, Pecorino Piemontese, and Pecorino Sardo), and both 2-heptanol and 2-nonanol (in Pecorino Leccese, Pecorino Sardo, and Pecorino Piemontese); and 

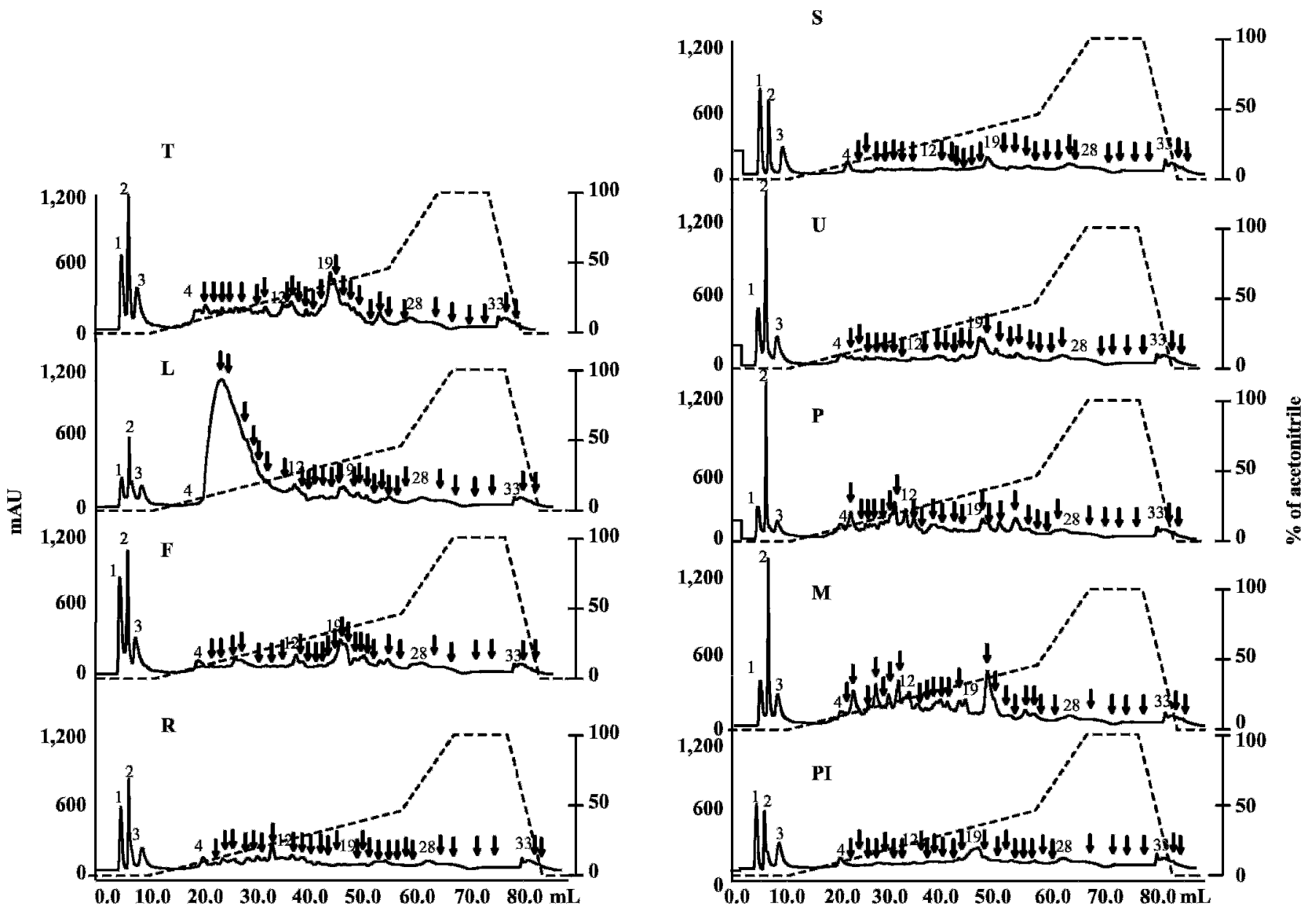

Figure 5. Reversed-phase fast-protein liquid chromatography of the pH 4.6-soluble fractions of 9 Italian Pecorino cheeses at the end of ripening. Chromatograms: T, Pecorino del Tarantino; L, Pecorino Leccese; F, Pecorino di Filiano; R, Pecorino del Reatino; S, Pecorino Sardo; U, Pecorino Umbro; P, Pecorino di Pienza; M, Pecorino Marchigiano; PI, Pecorino Piemontese. mAU = milli-arbitrary units.

branched-chain alcohols such as both 2-methyl-1-butanol and 3-methyl-1-butanol (in Pecorino Leccese, Pecorino Piemontese, Pecorino Marchigiano, and Pecorino del Tarantino) were identified as having the highest levels of these alcohol components.

Aldehydes were found at low levels in all the Pecorino cheeses (Table 3). Some aldehydes were found only in one cheese (e.g., 2-propenal in Pecorino Marchigiano) or at levels markedly higher in one cheese (e.g., 2-butenal, 2-methyl-2-butenal, and 2-ethyl-2-butenal in Pecorino Sardo) than in the others. 2-Methyl-butanal, 3-methyl-butanal, hexanal, benzaldehyde, and phenylacetaldehyde were identified in all cheeses. Lactones seemed to be a very minor fraction of the volatile components of the 9 Italian Pecorino cheeses (Table 3).

Among the miscellaneous components identified were methanethiol, dimethyl sulfide, dimethyl disulfide, and dimethyl trisulfide (the last 2 compounds especially in Pecorino del Tarantino and Pecorino Leccese), and vari- ous terpenes, without major differences among the cheeses with the exception of limonene, which was found at a very high level in Pecorino Sardo (Table 3). Pecorino di Pienza showed a level of 1,3-pentadiene approximately 20 -fold higher than the other cheeses (except for Pecorino Sardo).

\section{Volatile FFA}

Table 4 shows the profile of carboxylic acids found in the 9 Italian Pecorino cheeses. Nineteen volatile FFA were identified. The highest levels were found in Pecorino Umbro, Pecorino del Tarantino, and Pecorino di Filiano cheeses. Pecorino di Pienza was characterized by the lowest level. Although statistically significant differences were found among the cheeses, the FFA profiles were qualitatively similar. Ethanoic, butanoic, hexanoic, octanoic, and decanoic acids represented the largest proportions of the total of carboxylic acids, 


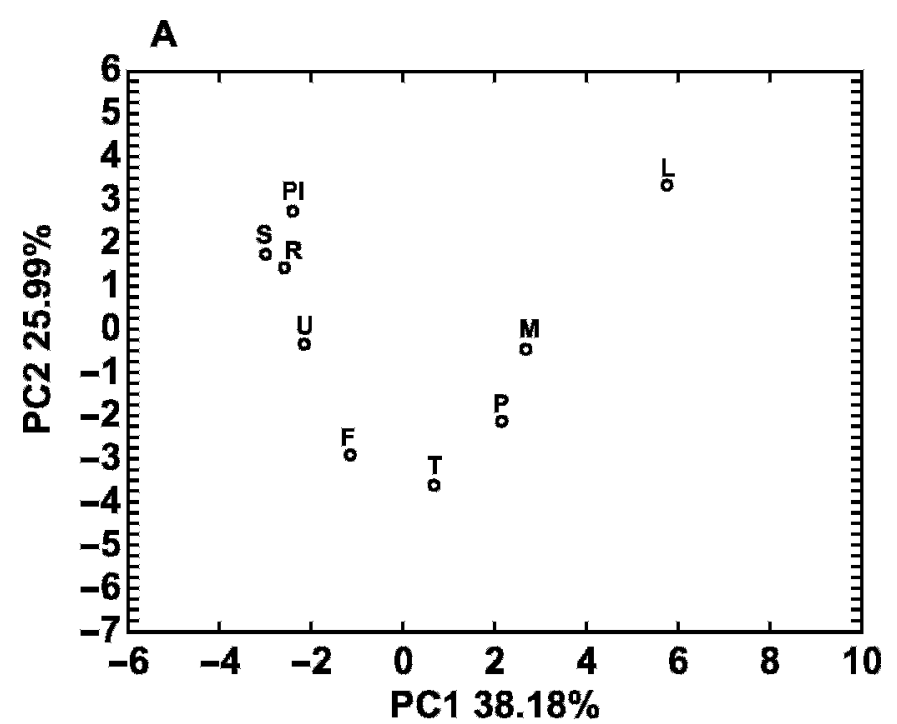

B

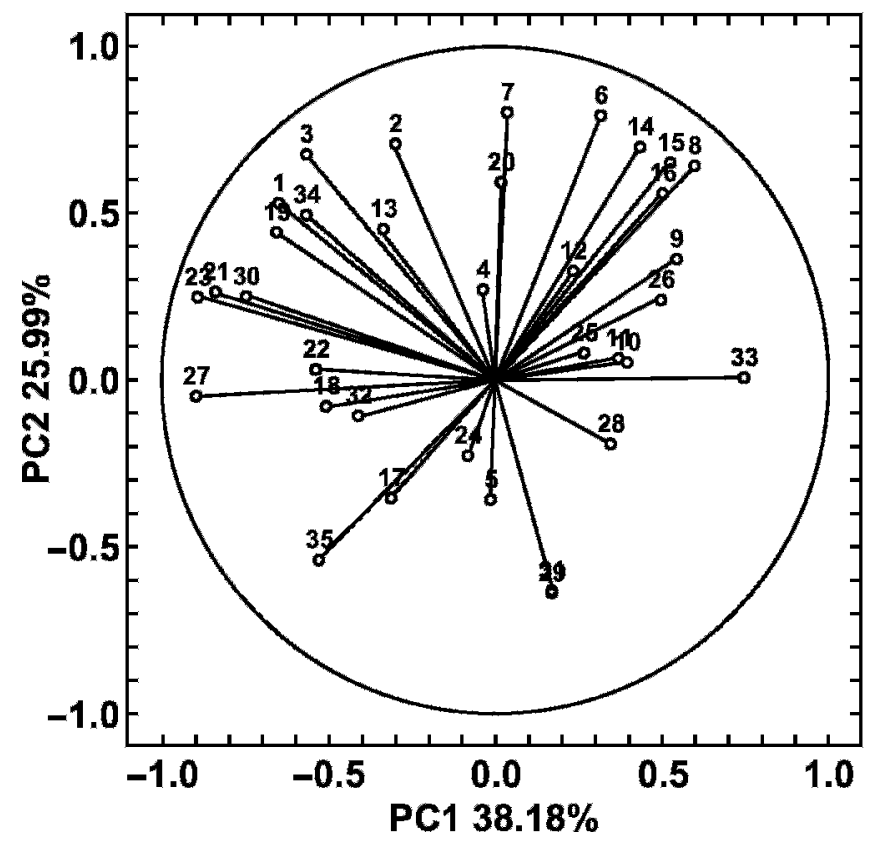

Figure 6. Score plot (A) and loading plot (B) of the first and second principal components (PC) after PC analysis based on individual peaks obtained from reversed-phase fast-protein liquid chromatograms of the $\mathrm{pH} 4.6$-soluble fractions of 9 Italian Pecorino cheeses at the end of ripening. T, Pecorino del Tarantino; L, Pecorino Leccese; F, Pecorino di Filiano; R, Pecorino del Reatino; S, Pecorino Sardo; U, Pecorino Umbro; P, Pecorino di Pienza; M, Pecorino Marchigiano; PI, Pecorino Piemontese.

which varied from $65.2 \%$ (Pecorino del Tarantino) to $82.6 \%$ (Pecorino Sardo).

\section{DISCUSSION}

Mean values for the gross composition were rather similar for cheeses, except for $\mathrm{pH}$. Cheeses manufac- tured by using primary starters showed the lowest $\mathrm{pH}$ values. The major role of primary starter cultures is to start the production of lactic acid from lactose, which occurs early in the manufacturing phase of cheese. Overall, in the early phase of manufacture NSLAB are present at very low numbers, significantly contributing to the decrease of $\mathrm{pH}$ (Berthier et al., 2001).

During cheese ripening, microbiology is frequently characterized by successions of communities. Whereas a large part $\left(\geq 8.0 \log _{10} \mathrm{cfu} / \mathrm{g}\right)$ of primary starter biomass declines throughout ripening, NSLAB increases from approximately $2.0 \log _{10} \mathrm{cfu} / \mathrm{g}$ in hygienically produced raw milk cheeses to $\geq 6.0 \log _{10} \mathrm{cfu} / \mathrm{g}$ in ripened cheese (Berthier et al., 2001). They grow at low temperature; are acid-tolerant; and tolerate the lack of fermentable carbohydrates, low $\mathrm{pH}$, and $\mathrm{a}_{\mathrm{w}}$ and the presence of bacteriocins, which make the environmental conditions very hostile during ripening. Nonstarter lactic acid bacteria find some components for growth in ripening cheese (e.g., lactate, citrate, glycerol, sugars, AA, and other metabolites; Peterson and Marshall, 1990; Wouters et al., 2002). The major part of the Italian Pecorino cheeses had $>6.0 \log _{10} \mathrm{cfu} / \mathrm{g}$ of NSLAB at the end of ripening. The only exception concerned Pecorino Umbro and Pecorino di Pienza cheeses, which were manufactured from pasteurized ewes' milk. Although some lactobacilli strains may survive the heat treatment (Jordan and Cogan, 1999), the majority are inactivated by pasteurization (Turner et al., 1986). However, recent studies have shown that the main source of NSLAB is milk (Buffa et al., 2001). Except for Pecorino di Pienza, which contained low numbers of $L b$. brevis, all the other cheeses contained $L b$. plantarum, $L b$. paracasei, or both as the dominant species of NSLAB. This finding is in agreement with several other studies aimed at characterizing the microbial composition of cheeses made from ewes' milk (Mannu et al., 2000; De Angelis et al., 2001; Di Cagno et al., 2003; Oneca et al., 2003; Macedo et al., 2004). In spite of the rather low differences at species level, the RAPD-PCR analyses highlighted a large biodiversity at the strain level. Although the role of NSLAB in the overall cheese quality is still debated because of the unpredictable and dynamic nature of nonstarter lactobacilli influenced by compositional and environmental factors (Lane et al., 1997), the positive contributions to flavor development by peptidase and AA catabolism activities of NSLAB have been reported (Poveda et al., 2002; Wouters et al., 2002).

Primary proteolysis of Italian Pecorino cheeses was characterized by the complete hydrolysis of $\alpha_{\mathrm{s} 1}-\mathrm{CN}$, which indicated considerable chymosin activity. Unlike other Italian ewes' milk cheeses (e.g., Pecorino Romano), the manufacture of these Pecorino cheeses did not include cooking of the curd. Under this condition, 
Table 2. Concentration $(\mathrm{mg} / \mathrm{g})^{1}$ of individual and total free AA of the 9 Italian Pecorino cheeses at the end of ripening

\begin{tabular}{lccccccccccccccccccccccc}
\hline Cheese & Asp & Thr & Ser & Glu & Pro & Gly & Ala & Cys & Val & Met & Ile & Leu & Tyr & Phe & His & Lys & Arg & Total & \\
\hline $\begin{array}{c}\text { Pecorino del } \\
\text { Tarantino }\end{array}$ & 4.74 & 0.23 & 0.26 & 3.85 & 0.99 & 0.18 & 0.52 & 0.22 & 1.10 & 0.52 & 1.94 & 1.79 & 0.33 & 1.14 & 0.26 & 1.38 & 0.01 & $21.83 \pm 0.50$ \\
$\begin{array}{c}\text { Pecorino } \\
\text { Leccese }\end{array}$ & 4.14 & 0.26 & 0.43 & 4.62 & 0.71 & 0.22 & 0.42 & 0.13 & 1.11 & 0.53 & 1.83 & 1.80 & 1.97 & 1.35 & 0.29 & 1.23 & 0 & $20.96 \pm 0.65$ \\
$\begin{array}{c}\text { Pecorino di } \\
\text { Filiano }\end{array}$ & 1.55 & 0.55 & 1.52 & 2.76 & 2.50 & 0.50 & 1.36 & 0.08 & 1.38 & 1.08 & 1.65 & 2.23 & 1.44 & 1.94 & 0.59 & 1.99 & 2.12 & $26.43 \pm 0.87$ \\
$\begin{array}{c}\text { Pecorino del } \\
\text { Reatino }\end{array}$ & 2.51 & 1.45 & 3.96 & 3.63 & 3.86 & 0.80 & 1.57 & 2.45 & 1.59 & 1.46 & 2.16 & 2.52 & 1.73 & 2.44 & 1.25 & 2.51 & 0.11 & $37.15 \pm 1.33$ \\
$\begin{array}{c}\text { Pecorino } \\
\quad \text { Sardo }\end{array}$ & 2.98 & 0.66 & 0 & 0 & 5.21 & 1.26 & 1.68 & 0.26 & 1.69 & 1.57 & 2.42 & 2.60 & 1.81 & 2.60 & 1.51 & 2.76 & 0.04 & $31.00 \pm 1.12$ \\
$\begin{array}{c}\text { Pecorino } \\
\text { Umbro }\end{array}$ & 0.18 & 0.11 & 0.43 & 1.33 & 0.33 & 0.11 & 0.62 & 0.14 & 1.17 & 0.38 & 0.42 & 1.79 & 0.33 & 1.28 & 0.23 & 0.61 & 0.18 & $10.58 \pm 0.13$ \\
$\begin{array}{c}\text { Pecorino di } \\
\text { Pienza }\end{array}$ & 0.20 & 0.10 & 0.56 & 1.04 & 0.44 & 0.06 & 0.21 & 0.40 & 0.13 & 0.25 & 0.31 & 1.17 & 0.45 & 0.93 & 2.04 & 0.58 & 0.02 & $9.13 \pm 0.21$ \\
$\begin{array}{c}\text { Pecorino } \\
\text { Marchigiano }\end{array}$ & 10.45 & 0.60 & 1.41 & 1.40 & 1.55 & 0.39 & 0.75 & 0.10 & 1.18 & 0.71 & 1.37 & 1.79 & 0.58 & 1.36 & 0.32 & 1.71 & 0.04 & $17.20 \pm 0.85$ \\
$\begin{array}{c}\text { Pecorino } \\
\text { Piemontese }\end{array}$ & 1.36 & 1.03 & 2.88 & 21.2 & 3.02 & 0.87 & 1.11 & 0.10 & 1.75 & 1.12 & 2.33 & 2.95 & 0.84 & 2.87 & 1.63 & 2.83 & 1.36 & $51.12 \pm 1.21$ \\
\hline
\end{tabular}

${ }^{1}$ Mean values \pm standard deviations for 3 batches of each type of cheese, analyzed in duplicate $(n=6)$.

chymosin activity toward $\alpha_{\mathrm{s} 1}$ - $\mathrm{CN}$ may proceed intensively during ripening. A considerable amount of $\beta$ $\mathrm{CN}$ persisted at the end of ripening. Overall, chymosin activity on $\beta$-CN is lower than that toward $\alpha_{\mathrm{s} 1}-\mathrm{CN}$, mainly because of hydrophobic interactions between salt and proteins (Fox, 1989). The same primary proteolysis was described during ripening of Canestrato Pugliese ewes' milk cheese (Albenzio et al., 2001). The PCA applied to chromatogram data of the $\mathrm{pH} 4.6$-soluble fractions (Poveda et al., 2002; Pripp et al., 2000) and the concentrations of free AA showed that secondary proteolysis varied among the Pecorino cheeses. The concentrations of free AA of some cheeses approached those found in other Italian ewes' milk cheeses ripened for longer times (Di Cagno et al., 2003). Pecorino Umbro and Pecorino di Pienza cheeses, which contained the lowest number of NSLAB, also had the lowest concentrations of free AA. Although the release of some AA seemed to be the highest in specific cheeses, Asp, Glu, Pro, Ile, Leu, Phe, and Lys were found at the highest concentrations in almost all the Pecorino cheeses. These AA are typically released during ripening of several Italian semihard and extra-hard cheese varieties (Resmini et al., 1988; Gobbetti et al., 1999; Albenzio et al., 2001; Di Cagno et al., 2003).

The SPME-GC-MS technique was used to characterize the volatile components of Italian Pecorino cheeses. Compared with other techniques, SPME-GC-MS was preferable because of its reduced sample preparation time, high sensitivity, and limited risk of artifacts caused by the use of solvents (Kataoka et al., 2000; Lord and Pawliszyn, 2000; Pinho et al., 2002). The SPME-GC-MS technique was also used previously to characterize the volatile profiles of Terrincho, Roncal,
Pecorino Sardo, and Fiore Sardo cheeses (Pinho et al., 2003b; Larràyoz et al., 2001). Quantitatively, alcohols were the most abundant chemical class for Pecorino Marchigiano, Pecorino Leccese, and Pecorino Piemontese, whereas ketones were the most abundant for the other cheeses. Overall, esters were the main volatile components of other Italian and Spanish cheeses also made from ewes' milk but ripened for longer times (e.g., Canestrato Pugliese, Pecorino Romano, Manchego, Roncal, Castellano; Martinez-Castro et al., 1991; Izco and Torre, 2000; Villasenor et al., 2000; Larráyoz et al., 2001; Di Cagno et al., 2003; Fernàndez-Garcìa et al., 2003). Nevertheless, esters, especially ethyl esters, were also found largely in the Pecorino cheeses. Esters contribute in a synergistic way to the fruity aroma of the cheese because they have a low perception threshold concentration that is 10 -fold lower than their alcohol precursors (Preininger and Grosch, 1994). Ethyl hexanoate, which has a distinct odor of unripe apple, and ethyl butanoate, which mainly characterizes cheeses containing the largest amounts of esters, were typically found to increase during the ripening of ewes' milk cheeses (Mariaca et al., 2001; Di Cagno et al., 2003). Ethyl-2-methyl-butanoate and -propanoate, and ethyl3 -methyl-butanoate were found only in cheeses produced in the Apulia region. 2-Alkanones with odd numbers of carbon atoms were found, with differences in the amounts of individual compounds depending on the Pecorino cheese. Free fatty acids liberated through lipolysis might be catabolized to methyl ketones by microbial activity (Izco and Torre, 2000). Ketones also characterized the profiles of Fiore Sardo and Manchego cheeses when manufactured with raw ewes' milk (Villasenor et al., 2000; Di Cagno et al., 2003). 2-Pentanone 
Table 3. Volatile components ${ }^{1}$ (area $\times \mathrm{e}^{5} / 1 \mathrm{~g}$ of sample) found in the 9 Italian Pecorino cheeses at the end of ripening

\begin{tabular}{|c|c|c|c|c|c|c|c|c|c|c|c|c|}
\hline \multirow[b]{3}{*}{ Chemical class } & \multirow{3}{*}{$\begin{array}{l}\text { Pecorino } \\
\text { del Tarantino }\end{array}$} & \multirow{3}{*}{$\begin{array}{l}\text { Pecorino } \\
\text { Leccese }\end{array}$} & \multirow{3}{*}{$\begin{array}{l}\text { Pecorino } \\
\text { di Filiano }\end{array}$} & \multirow{3}{*}{$\begin{array}{l}\text { Pecorino } \\
\text { del Reatino }\end{array}$} & \multirow{3}{*}{$\begin{array}{l}\text { Pecorino } \\
\text { Sardo }\end{array}$} & \multirow{3}{*}{$\begin{array}{l}\text { Pecorino } \\
\text { Umbro }\end{array}$} & \multirow{3}{*}{$\begin{array}{l}\text { Pecorino } \\
\text { di Pienza }\end{array}$} & \multirow{3}{*}{$\begin{array}{l}\text { Pecorino } \\
\text { Marchigiano }\end{array}$} & \multirow{3}{*}{$\begin{array}{l}\text { Pecorino } \\
\text { Piemontese }\end{array}$} & \multicolumn{3}{|c|}{ Significance } \\
\hline & & & & & & & & & & \multicolumn{2}{|c|}{ Cheese $^{2}$} & \multirow{2}{*}{$\frac{\text { Sample }^{3}}{P}$} \\
\hline & & & & & & & & & & $F$ & $P$ & \\
\hline \multicolumn{13}{|l|}{ Esters } \\
\hline Methyl butanoate & 0.96 & 1.10 & 0.97 & 0.82 & 2.45 & 1.38 & 0.72 & 1.35 & 1.66 & $\Delta \Delta$ & $* * *$ & NS \\
\hline Methyl octanoate & 0.84 & 0.82 & 0.58 & 0.83 & 2.61 & 0.90 & 0.60 & 0.89 & 0.68 & $\overline{\Delta \Delta}$ & $* * *$ & NS \\
\hline Ethyl acetate & 7.94 & 17.79 & 4.68 & 3.18 & 6.89 & 3.37 & 2.96 & 25.42 & 17.42 & $\Delta \Delta \Delta \Delta$ & $* * *$ & $* * *$ \\
\hline Ethyl propanoate & 2.06 & 2.20 & 0.00 & 0.00 & 1.29 & 0.21 & 0.00 & 2.67 & 4.09 & $\Delta \Delta \Delta \Delta$ & $* * *$ & NS \\
\hline Ethyl-2-methyl- & & & & & & & & & & & & \\
\hline propanoate & 1.51 & 1.70 & 0.00 & 0.00 & 0.00 & 0.00 & 0.00 & 0.00 & 0.00 & $\Delta \Delta \Delta$ & $* * *$ & * \\
\hline Ethyl butanoate & 11.05 & 14.10 & 11.39 & 4.97 & 13.1 & 9.08 & 3.46 & 16.97 & 22.46 & $\Delta \Delta$ & $* * *$ & * \\
\hline Ethyl-2-butanoate & 0.00 & 2.07 & 0.00 & 0.00 & 0.00 & 0.00 & 0.00 & 0.00 & 0.47 & $\Delta \Delta \Delta \Delta$ & $* * *$ & $* * *$ \\
\hline Ethyl-2-methyl- & & & & & & & & & & & & \\
\hline butanoate & 0.58 & 0.52 & 0.00 & 0.00 & 0.00 & 0.00 & 0.00 & 0.00 & 0.00 & $\Delta \Delta \Delta \Delta$ & $* * *$ & $* * *$ \\
\hline Ethyl-3-methyl- & & & & & & & & & & & & \\
\hline butanoate & 0.98 & 0.98 & 0.00 & 0.00 & 0.00 & 0.00 & 0.00 & 0.00 & 0.00 & $\Delta \Delta \Delta \Delta$ & $* * *$ & $* * *$ \\
\hline Ethyl pentanoate & 1.01 & 1.09 & 0.76 & 0.54 & 1.09 & 0.68 & 0.00 & 1.44 & 2.22 & $\Delta \Delta \Delta$ & $* * *$ & * \\
\hline Ethyl hexanoate & 10.81 & 9.54 & 9.01 & 3.70 & 10.82 & 9.54 & 2.16 & 12.56 & 14.28 & $\Delta \Delta$ & $* * *$ & * \\
\hline Ethyl octanoate & 3.68 & 3.70 & 3.65 & 1.75 & 5.41 & 3.63 & 1.13 & 6.76 & 5.77 & $\Delta$ & $* * *$ & NS \\
\hline Ethyl decanoate & 2.88 & 2.60 & 2.67 & 1.63 & 2.87 & 3.31 & 1.17 & 4.22 & 2.86 & $\Delta$ & $* * *$ & NS \\
\hline Ethyl-9-decenoate & 0.00 & 0.00 & 0.00 & 0.00 & 0.20 & 0.53 & 0.00 & 0.72 & 0.65 & $\Delta \Delta$ & $* * *$ & $* * *$ \\
\hline Propyl acetate & 2.48 & 0.59 & 0.87 & 0.00 & 3.85 & 0.00 & 0.00 & 1.94 & 0.77 & $\vec{\Delta} \Delta \Delta$ & $* * *$ & $* *$ \\
\hline Propyl butanoate & 2.78 & 0.96 & 1.88 & 0.66 & 6.25 & 0.84 & 0.05 & 1.43 & 1.55 & $\Delta \Delta \Delta \Delta$ & $* * *$ & NS \\
\hline Propyl hexanoate & 1.98 & 0.58 & 0.98 & 0.56 & 3.67 & 0.69 & 0.39 & 0.60 & 0.32 & $\Delta \Delta$ & $* * *$ & NS \\
\hline Propyl octanoate & 0.37 & 0.00 & 0.22 & 0.28 & 1.19 & 0.00 & 0.00 & 0.07 & 0.00 & $\Delta \Delta$ & $* * *$ & NS \\
\hline Butyl acetate & 1.54 & 1.11 & 5.74 & 1.06 & 3.53 & 0.62 & 0.75 & 0.59 & 1.40 & $\Delta \Delta$ & $* * *$ & NS \\
\hline Butyl butanoate & 1.56 & 0.64 & 6.14 & 0.77 & 3.38 & 1.26 & 0.31 & 0.00 & 1.06 & $\Delta \Delta \Delta$ & $* * *$ & NS \\
\hline Butyl hexanoate & 1.11 & 1.03 & 2.86 & 0.59 & 1.18 & 0.73 & 0.09 & 0.00 & 0.70 & $\Delta \Delta$ & $* * *$ & $*$ \\
\hline Butyl octanoate & 0.28 & 1.75 & 0.75 & 0.00 & 0.54 & 3.91 & 0.00 & 0.00 & 0.00 & $\Delta \Delta \Delta$ & $* * *$ & * \\
\hline 3-Methylbutyl acetate & 3.2 & 4.02 & 1.74 & 0.00 & 5.87 & 0.00 & 0.00 & 2.21 & 0.00 & $\Delta \Delta \Delta$ & $* * *$ & $* * *$ \\
\hline 3-Methylbutyl butanoate & 1.99 & 2.60 & 0.46 & 0.47 & 0.86 & 0.58 & 0.04 & 1.20 & 1.53 & $\Delta \Delta$ & $* * *$ & NS \\
\hline Diethyl succinate & 0.00 & 0.00 & 0.00 & 0.00 & 0.00 & 0.00 & 0.00 & 1.10 & 0.00 & $\Delta \Delta \Delta \Delta$ & $* * *$ & $* * *$ \\
\hline Total esters & 50.78 & 71.49 & 55.35 & 18.63 & 75.05 & 41.26 & 13.83 & 82.14 & 79.89 & & & \\
\hline \multicolumn{13}{|l|}{ Ketones } \\
\hline 2-Propanone & 8.38 & 5.60 & 8.36 & 10.13 & 8.36 & 7.59 & 17.04 & 3.33 & 8.81 & $\Delta \Delta \Delta$ & $* * *$ & * \\
\hline 2-Butanone & 30.56 & 5.46 & 5.36 & 4.69 & 11.64 & 8.55 & 6.07 & 32.42 & 8.68 & $\Delta$ & $* * *$ & NS \\
\hline 2-Pentanone & 11.72 & 21.27 & 13.45 & 24.85 & 20.23 & 10.48 & 37.6 & 10.62 & 20.22 & $\Delta \Delta$ & $* * *$ & $*$ \\
\hline 4-Methyl-2-pentanone & 1.33 & 0.00 & 0.00 & 1.08 & 0.91 & 0.00 & 1.09 & 0.00 & 0.91 & $\Delta$ & $* * *$ & $* * *$ \\
\hline 3-Methyl-2-pentanone & 1.75 & 0.87 & 0.00 & 1.11 & 0.63 & 0.00 & 0.57 & 0.00 & 0.90 & $\Delta \Delta$ & $* * *$ & NS \\
\hline 2-Hexanone & 1.74 & 3.46 & 2.62 & 4.92 & 3.05 & 1.55 & 6.24 & 2.36 & 2.96 & $\Delta \Delta$ & $* * *$ & $*$ \\
\hline 2-Heptanone & 8.84 & 20.58 & 17.43 & 27.09 & 20.05 & 10.69 & 33.16 & 14.15 & 14.54 & $\Delta \Delta$ & $* * *$ & NS \\
\hline 6-Methyl-5-hepten-2-one & 0.00 & 0.00 & 0.00 & 0.00 & 0.86 & 0.00 & 0.00 & 0.00 & 0.00 & $\Delta$ & $* * *$ & NS \\
\hline 2-Octanone & 0.93 & 2.34 & 3.32 & 3.56 & 2.74 & 1.33 & 4.13 & 2.20 & 1.77 & $\Delta$ & $* * *$ & NS \\
\hline 2-Nonanone & 4.64 & 8.62 & 16.91 & 13.64 & 13.43 & 5.45 & 16.80 & 11.51 & 6.89 & I & $* * *$ & NS \\
\hline 2-Undecanone & 1.20 & 1.41 & 2.25 & 1.34 & 2.04 & 0.70 & 2.29 & 2.10 & 1.42 & I & $* * *$ & NS \\
\hline 3-Octanone & 0.55 & 0.48 & 0.37 & 0.43 & 0.51 & 0.42 & 0.60 & 1.04 & 0.53 & I & $* * *$ & NS \\
\hline 1-Hydroxy-2-propanone & 1.34 & 0.00 & 1.42 & 1.66 & 0.36 & 1.68 & 2.06 & 0.00 & 0.00 & $\Delta \Delta$ & $* * *$ & NS \\
\hline 3-Hydroxy-2-butanone & 12.69 & 5.05 & 5.92 & 4.17 & 5.80 & 6.65 & 9.22 & 2.21 & 4.24 & $\Delta \Delta$ & $* * *$ & $* * * *$ \\
\hline 3-Hydroxy-2-pentanone & 1.95 & 1.07 & 1.42 & 1.13 & 1.40 & 1.15 & 1.05 & 0.62 & 0.90 & $\Delta \Delta$ & $* * *$ & NS \\
\hline \multirow{3}{*}{ Diacetyl } & 1.81 & 0.95 & 0.93 & 1.07 & 1.80 & 1.16 & 0.98 & 0.74 & 0.96 & $\Delta$ & $* * *$ & NS \\
\hline & 9.22 & 7.77 & 8.78 & 7.77 & 6.44 & 6.90 & 11.27 & 0.00 & 6.00 & / & $* * *$ & NS \\
\hline & & & & & & & & & & & \multicolumn{2}{|c|}{ Continued } \\
\hline
\end{tabular}




\begin{tabular}{|c|c|c|c|c|c|c|c|c|c|c|c|c|}
\hline \multirow[b]{3}{*}{ Chemical class } & \multirow{3}{*}{$\begin{array}{l}\text { Pecorino } \\
\text { del Tarantino }\end{array}$} & \multirow{3}{*}{$\begin{array}{l}\text { Pecorino } \\
\text { Leccese }\end{array}$} & \multirow{3}{*}{$\begin{array}{l}\text { Pecorino } \\
\text { di Filiano }\end{array}$} & \multirow{3}{*}{$\begin{array}{l}\text { Pecorino } \\
\text { del Reatino }\end{array}$} & \multirow{3}{*}{$\begin{array}{l}\text { Pecorino } \\
\text { Sardo }\end{array}$} & \multirow{3}{*}{$\begin{array}{l}\text { Pecorino } \\
\text { Umbro }\end{array}$} & \multirow{3}{*}{$\begin{array}{l}\text { Pecorino } \\
\text { di Pienza }\end{array}$} & \multirow{3}{*}{$\begin{array}{l}\text { Pecorino } \\
\text { Marchigiano }\end{array}$} & \multirow{3}{*}{$\begin{array}{l}\text { Pecorino } \\
\text { Piemontese }\end{array}$} & \multicolumn{3}{|c|}{ Significance } \\
\hline & & & & & & & & & & \multicolumn{2}{|c|}{ Cheese $^{2}$} & \multirow{2}{*}{$\frac{\text { Sample }^{3}}{P}$} \\
\hline & & & & & & & & & & $F$ & $P$ & \\
\hline 2,3-Pentanedione & 1.87 & 1.13 & 0.94 & 1.67 & 2.13 & 1.05 & 2.68 & 1.28 & 0.95 & / & $* * *$ & NS \\
\hline Acetophenone & 0.33 & 0.37 & 0.43 & 0.58 & 0.46 & 0.55 & 0.47 & 0.48 & 0.48 & / & $* * *$ & NS \\
\hline Phenylacetone & 0.73 & 0.00 & 0.00 & 0.00 & 0.00 & 0.00 & 0.00 & 0.00 & 0.00 & $\Delta \Delta$ & $* * *$ & $*$ \\
\hline Total ketones & 101.58 & 86.43 & 89.91 & 110.89 & 102.84 & 65.90 & 153.32 & 85.06 & 81.16 & & & \\
\hline \multicolumn{13}{|l|}{ Alcohols } \\
\hline Ethanol & 15.90 & 26.22 & 12.99 & 6.89 & 15.71 & 10.75 & 11.66 & 35.29 & 33.14 & $\Delta \Delta \Delta \Delta$ & $* * *$ & NS \\
\hline 2-Propen-1-ol & 0.00 & 0.00 & 0.00 & 0.00 & 0.00 & 0.00 & 0.00 & 4.62 & 0.00 & $\Delta \Delta \Delta \Delta$ & $* * *$ & $* * *$ \\
\hline 2-Methyl-1-propanol & 1.00 & 2.65 & 0.00 & 0.00 & 0.91 & 0.00 & 1.41 & 1.87 & 1.94 & $\Delta \Delta$ & $* * *$ & NS \\
\hline 1-Butanol & 4.46 & 3.22 & 10.29 & 2.04 & 7.41 & 1.81 & 1.25 & 2.89 & 4.60 & $\Delta$ & $* * *$ & NS \\
\hline 2-Buten-1-ol & 0.00 & 0.00 & 0.00 & 0.00 & 1.75 & 0.00 & 0.00 & 0.66 & 0.00 & $\Delta \Delta \Delta \Delta$ & $* * *$ & $* * *$ \\
\hline 2-Methyl-1-butanol & 2.33 & 4.61 & 0.52 & 0.60 & 1.12 & 0.85 & 1.11 & 2.99 & 3.06 & $\Delta \Delta \Delta$ & $* * *$ & * \\
\hline 3-Methyl-1-butanol & 4.76 & 8.79 & 0.95 & 1.26 & 1.75 & 0.92 & 2.69 & 5.11 & 5.59 & $\Delta \Delta \Delta$ & $* * *$ & NS \\
\hline 3-Methyl-3-buten-1-ol & 0.93 & 1.09 & 0.59 & 0.78 & 1.31 & 0.50 & 1.10 & 0.73 & 0.96 & I & $* * *$ & NS \\
\hline 3-Methyl-2-buten-1-ol & 0.81 & 1.05 & 0.64 & 0.81 & 1.21 & 0.45 & 1.22 & 0.73 & 1.00 & $\Delta$ & $* * *$ & NS \\
\hline 1-Pentanol & 1.05 & 3.00 & 1.71 & 2.56 & 1.64 & 1.09 & 4.87 & 2.37 & 1.78 & $\Delta \Delta \Delta \Delta$ & $* * *$ & $* * *$ \\
\hline 1-Hexanol & 3.12 & 2.29 & 6.49 & 1.68 & 3.77 & 1.98 & 1.51 & 3.75 & 4.05 & $\Delta$ & $* * *$ & NS \\
\hline 2-Ethyl-1-hexanol & 1.49 & 0.67 & 0.94 & 1.24 & 1.39 & 0.76 & 1.39 & 1.34 & 1.35 & 1 & $* * *$ & $*$ \\
\hline 1-Octanol & 0.90 & 0.56 & 0.70 & 0.53 & 0.71 & 0.49 & 0.50 & 0.91 & 0.79 & / & $* * *$ & NS \\
\hline 2-Propanol & 2.62 & 4.74 & 3.68 & 1.43 & 4.60 & 1.68 & 1.32 & 1.41 & 4.35 & $\Delta \Delta$ & $* * *$ & * \\
\hline 2-Butanol & 10.43 & 4.58 & 3.71 & 1.37 & 10.99 & 2.73 & 1.16 & 19.61 & 2.81 & $\Delta \Delta \Delta$ & $* * *$ & $* * *$ \\
\hline 2-Pentanol & 4.69 & 17.91 & 5.80 & 7.50 & 10.69 & 2.66 & 4.22 & 6.16 & 13.57 & $\Delta \Delta$ & $* * *$ & NS \\
\hline 2-Hexanol & 0.68 & 2.70 & 0.00 & 1.25 & 1.59 & 0.00 & 0.84 & 1.26 & 1.93 & $\Delta \Delta \Delta \Delta$ & $* * *$ & NS \\
\hline 2-Heptanol & 3.79 & 9.93 & 4.29 & 5.29 & 8.15 & 2.10 & 4.00 & 7.69 & 8.30 & $\Delta \Delta$ & $* * *$ & NS \\
\hline 2-Nonanol & 1.23 & 2.00 & 2.31 & 2.54 & 4.05 & 0.68 & 2.13 & 3.55 & 3.09 & I & $* * *$ & NS \\
\hline 3-Ethoxy-1-propanol & 0.00 & 0.00 & 0.00 & 0.00 & 0.00 & 0.00 & 0.00 & 1.36 & 0.00 & $\Delta \Delta \Delta \Delta$ & $* * *$ & NS \\
\hline 2-Butoxy-ethanol & 0.00 & 3.30 & 0.26 & 0.84 & 0.93 & 0.97 & 1.04 & 1.00 & 1.49 & $\Delta$ & $* * *$ & $* * *$ \\
\hline 1-Butoxy-2-propanol & 0.00 & 0.00 & 0.00 & 1.04 & 0.00 & 0.00 & 0.00 & 0.55 & 2.07 & $\Delta \Delta$ & $* * *$ & $* * *$ \\
\hline Benzyl & 0.22 & 0.39 & 0.11 & 0.80 & 0.45 & 0.94 & 0.30 & 0.76 & 1.01 & $\Delta$ & $* * *$ & NS \\
\hline Phenethyl & 1.35 & 1.86 & 0.95 & 0.75 & 0.45 & 0.86 & 0.85 & 2.63 & 2.45 & $\Delta$ & $* * *$ & $*$ \\
\hline Total alcohols & 61.76 & 101.56 & 56.93 & 41.20 & 72.50 & 42.97 & 44.57 & 109.24 & 99.33 & & & \\
\hline \multicolumn{13}{|l|}{ Aldehydes } \\
\hline 2-Propenal & 0.00 & 0.00 & 0.00 & 0.00 & 0.00 & 0.00 & 0.00 & 2.36 & 0.00 & $\Delta \Delta \Delta \Delta$ & $* * *$ & $* * *$ \\
\hline 2-Methyl-propanal & 0.43 & 0.40 & 0.45 & 1.25 & 1.17 & 0.65 & 0.62 & 0.00 & 0.54 & $\Delta \Delta$ & $* * *$ & $* *$ \\
\hline Butanal & 0.15 & 0.07 & 0.60 & 0.93 & 0.97 & 0.78 & 0.53 & 0.00 & 0.00 & $\Delta \Delta$ & $* * *$ & NS \\
\hline 2-Butenal & 0.00 & 0.00 & 0.00 & 1.82 & 12.07 & 0.00 & 0.39 & 0.00 & 0.00 & $\Delta \Delta \Delta \Delta$ & $* * *$ & NS \\
\hline 2-Methyl-2-butenal & 0.00 & 0.00 & 0.00 & 0.60 & 2.42 & 0.32 & 0.00 & 0.77 & 0.00 & $\Delta \Delta \Delta$ & $* * *$ & NS \\
\hline 2-Ethyl-2-butenal & 0.00 & 0.00 & 0.00 & 0.00 & 2.70 & 0.00 & 0.00 & 0.33 & 0.00 & $\Delta \Delta \Delta \Delta$ & $* * *$ & $* * *$ \\
\hline 2-Methyl-butanal & 0.85 & 0.65 & 0.83 & 2.17 & 1.79 & 0.84 & 0.68 & 0.24 & 1.01 & $\Delta \Delta \Delta \Delta$ & $* * *$ & $* * *$ \\
\hline 3-Methyl-butanal & 1.75 & 1.23 & 1.50 & 3.07 & 1.95 & 1.34 & 1.89 & 0.48 & 1.64 & $\Delta$ & $* * *$ & NS \\
\hline Hexanal & 1.29 & 1.28 & 1.37 & 1.66 & 1.70 & 1.47 & 2.32 & 2.70 & 1.67 & 1 & $* * *$ & $* * *$ \\
\hline Benzaldehyde & 0.80 & 0.80 & 1.09 & 2.13 & 2.06 & 1.87 & 1.52 & 1.07 & 0.98 & I & $* * *$ & NS \\
\hline Phenylacetaldehyde & 0.90 & 0.73 & 0.62 & 1.25 & 0.95 & 1.06 & 1.01 & 0.62 & 1.23 & I & $* * *$ & NS \\
\hline Methional & 0.00 & 0.00 & 0.17 & 1.35 & 0.80 & 0.63 & 0.14 & 0.00 & 0.00 & $\Delta \Delta$ & $* * *$ & $* *$ \\
\hline Total aldhehydes & 6.17 & 5.16 & 6.63 & 16.23 & 28.58 & 8.96 & 9.10 & 8.57 & 7.07 & & & \\
\hline
\end{tabular}




\begin{tabular}{|c|c|c|c|c|c|c|c|c|c|c|c|c|}
\hline \multirow[b]{3}{*}{ Chemical class } & \multirow{3}{*}{$\begin{array}{l}\text { Pecorino } \\
\text { del Tarantino }\end{array}$} & \multirow{3}{*}{$\begin{array}{l}\text { Pecorino } \\
\text { Leccese }\end{array}$} & \multirow{3}{*}{$\begin{array}{l}\text { Pecorino } \\
\text { di Filiano }\end{array}$} & \multirow{3}{*}{$\begin{array}{l}\text { Pecorino } \\
\text { del Reatino }\end{array}$} & \multirow{3}{*}{$\begin{array}{l}\text { Pecorino } \\
\text { Sardo }\end{array}$} & \multirow{3}{*}{$\begin{array}{l}\text { Pecorino } \\
\text { Umbro }\end{array}$} & \multirow{3}{*}{$\begin{array}{l}\text { Pecorino } \\
\text { di Pienza }\end{array}$} & \multirow{3}{*}{$\begin{array}{l}\text { Pecorino } \\
\text { Marchigiano }\end{array}$} & \multirow{3}{*}{$\begin{array}{l}\text { Pecorino } \\
\text { Piemontese }\end{array}$} & \multicolumn{3}{|c|}{ Significance } \\
\hline & & & & & & & & & & \multicolumn{2}{|c|}{ Cheese $^{2}$} & \multirow{2}{*}{$\frac{\text { Sample }^{3}}{P}$} \\
\hline & & & & & & & & & & $F$ & $P$ & \\
\hline \multicolumn{13}{|l|}{ Carboxylic acids } \\
\hline Benzoic acid & 1.09 & 1.13 & 1.04 & 1.04 & 0.85 & 1.09 & 1.16 & 0.97 & 0.75 & I & $* * *$ & ** \\
\hline Formic acid & 1.48 & 1.76 & 1.85 & 0.99 & 1.55 & 3.44 & 2.64 & 2.52 & 1.09 & $\Delta \Delta$ & $* * *$ & NS \\
\hline Ethanoic acid & 24.90 & 25.34 & 22.19 & 14.33 & 20.25 & 26.77 & 11.93 & 20.21 & 16.80 & $\Delta \bar{\Delta}$ & $* * *$ & NS \\
\hline Propanoic acid & 9.72 & 3.14 & 2.79 & 2.34 & 2.78 & 2.97 & 1.62 & 6.49 & 3.75 & $\Delta \Delta \Delta$ & $* * *$ & NS \\
\hline 2-Methyl propanoic acid & 11.21 & 5.80 & 4.44 & 3.48 & 1.69 & 2.90 & 2.78 & 1.56 & 4.13 & $\Delta \Delta \Delta \Delta$ & $* * *$ & $* * *$ \\
\hline Butanoic acid & 31.82 & 26.26 & 40.57 & 36.49 & 32.04 & 44.24 & 23.66 & 27.86 & 29.14 & $\Delta \Delta$ & $* * *$ & NS \\
\hline 2-Methyl-butanoic acid & 9.14 & 3.85 & 3.22 & 2.66 & 1.03 & 1.32 & 1.09 & 0.94 & 3.36 & $\Delta \Delta \Delta$ & $* * *$ & $* * *$ \\
\hline 3-Methyl-butanoic acid & 10.75 & 4.83 & 5.82 & 4.74 & 1.24 & 3.03 & 2.15 & 1.95 & 7.62 & $\Delta \Delta$ & $* * *$ & $* *$ \\
\hline 3-Methyl-2-butenoic acid & 0.98 & 0.00 & 0.00 & 0.00 & 0.00 & 0.00 & 0.00 & 0.00 & 0.00 & $\Delta \Delta \Delta \Delta$ & $* * *$ & NS \\
\hline Pentanoic acid & 4.31 & 2.90 & 5.62 & 5.81 & 3.95 & 7.98 & 2.49 & 3.48 & 3.57 & $\Delta \Delta$ & $* * *$ & NS \\
\hline Hexanoic acid & 27.93 & 19.74 & 31.49 & 28.77 & 26.41 & 34.67 & 14.57 & 21.11 & 18.88 & $\Delta \Delta$ & $* * *$ & NS \\
\hline 5-Hexenoic acid & 1.28 & 0.00 & 0.00 & 0.00 & 1.38 & 0.00 & 0.00 & 0.14 & 0.00 & $\Delta \Delta$ & $* * *$ & NS \\
\hline 2,4-Hexadienoic acid & 0.00 & 0.00 & 0.00 & 0.00 & 0.31 & 0.00 & 1.12 & 0.00 & 0.00 & $\Delta \Delta \Delta$ & $* * *$ & $* * *$ \\
\hline 4-Methyl-hexanoic acid & 0.97 & 0.00 & 0.00 & 0.00 & 0.31 & 0.00 & 0.00 & 0.00 & 0.00 & $\Delta \Delta$ & $* * *$ & $* * *$ \\
\hline Heptanoic acid & 3.06 & 2.13 & 3.42 & 3.74 & 3.37 & 4.82 & 1.53 & 2.19 & 1.86 & $\Delta \Delta$ & $* * *$ & NS \\
\hline Octanoic acid & 14.46 & 9.51 & 16.93 & 14.22 & 14.86 & 19.73 & 7.51 & 8.66 & 7.22 & $\Delta$ & $* * *$ & NS \\
\hline Nonanoic acid & 1.85 & 1.46 & 1.96 & 1.65 & 1.57 & 1.48 & 0.98 & 1.19 & 0.98 & / & $* * *$ & NS \\
\hline Decanoic acid & 7.30 & 4.45 & 6.75 & 6.40 & 5.73 & 9.15 & 3.96 & 3.88 & 3.23 & I & $* * *$ & NS \\
\hline 9-Decenoic acid & 1.05 & 0.53 & 1.10 & 0.95 & 0.83 & 1.49 & 0.58 & 0.60 & 0.60 & I & $* * *$ & NS \\
\hline Total carboxylic acids & 163.30 & 112.83 & 149.19 & 127.61 & 120.15 & 165.08 & 79.77 & 103.75 & 102.98 & & & \\
\hline
\end{tabular}

${ }^{1}$ Average value for 3 batches of each type of cheese, analyzed in duplicate $(n=6)$.

${ }^{2}$ Statistical significance among the 9 Pecorino cheeses.

${ }^{3}$ Statistical significance among the 3 batches of each type of cheese. $F$-values are coded as follows: range $50 / ; 50$ to $99 \Delta ; 100$ to $499 \Delta \Delta ; 500$ to $999 \Delta \Delta \Delta ;>1,000 \Delta \Delta \Delta \Delta$. $P$-values are coded as follows: *** $P<0.001 ; * * P<0.01 ; * P<0.05 ;$ NS $(P>0.05)$. 
was the most abundant methyl ketone in aged Manchego cheese (Villasenor et al., 2000) and may impart an orange-peel aroma to cheese because of its much lower perception threshold than the other ketones (Arora et al., 1995). 3-Hydroxy-2-butanone (acetoin) was detected at the highest concentrations in Fiore Sardo, Pecorino Romano, Canestrato Pugliese, and Roncal ewes' milk cheeses (Izco and Torre, 2000; Di Cagno et al., 2003). Because of its low perception threshold (0.12 $\mathrm{mg} / \mathrm{kg}$ ), the effect of 3-hydroxy-2-butanone on the aroma of Roncal cheese was considered very important. Acetoin is produced by the reduction of diacetyl (2,3-butanedione) or it may be synthesized from pyruvate, lactose, or citrate by lactic acid bacteria (Crow, 1990). Overall, the strong reducing conditions in cheese may favor the rapid reduction of aldehydes and ketones to primary and secondary alcohols (Molimard and Spinnler, 1996). Although primary alcohols were found mainly in Pecorino di Filiano cheese, secondary and branched-chain alcohols mainly distinguished Pecorino Leccese, Pecorino Piemontese, and Pecorino Sardo cheeses. Manchego cheese showed the largest percentage of primary alcohols, whereas Zamorano cheese showed the largest percentage of branched-chain alcohols (Barron et al., 2004). Alcohols were quantitatively the main chemical family found in the volatile fraction of La Serena and Castellano cheeses (Carbonell et al., 2002; Fernàndez-Garcìa et al., 2003). Secondary alcohols such as 2-pentanol and 2-heptanol may be derived by the reduction of methyl ketones by microbial reductases as a defense mechanism against toxicity (Molimard and Spinnler, 1996). 3-Methyl-1-butanol has a fruity (Karahadian et al., 1985), fusel oil, or whisky odor (Moio and Addeo, 1998) and is responsible for the pleasant aroma of fresh cheese. Methyl-branched alcohols may be derived through the reduction of aldehydes formed via Strecker degradation from AA (Jollivet et al., 1994). Compared with the other volatile components, aldehydes were found at low levels in all the Pecorino cheeses. This was in agreement with the volatile profile of other Italian cheeses such as Pecorino Romano, Fiore Sardo, and Canestrato Pugliese (Di Cagno et al., 2003). The low level of aldehydes indicated an optimal maturation because a higher concentration of aldehydes may cause off-flavors (Moio and Addeo, 1998). Aldehydes are unstable compounds that are reduced to alcohols or oxidized to acids during cheese ripening (Carbonell et al., 2002). Limonene was found at a level approximately 8-fold higher in Pecorino Sardo, and the level of 1,3pentadiene was markedly higher in Pecorino Sardo and especially in Pecorino di Pienza compared with the other cheeses. Their presence in cheese is probably not related to the ripening process but to the ewes' diet (Carbonell et al., 2002). Methional, dimethyl disulfide, and dimethyl trisulfide were probably related to the breakdown of the sulfur-containing AA during ripening by microbial enzymes, which produced hydrogen sulfide and methanethiol, which after oxidation may yield the above components. Those compounds are considered indispensable for the characteristic aroma of cheeses such as Cheddar and Emmenthal, but some authors speculate (Izco and Torre, 2000) that they are not particularly important for the aroma of Spanish ewes' milk cheeses.

The strong, balanced piquant flavor that characterizes Pecorino cheeses is primarily due to the relatively high levels of short-chain FFA. Except for Pecorino di Pienza, which showed the lowest level of FFA, all the other cheeses were manufactured by using rennet paste. It contains the pregastric esterase, which preferentially hydrolyzes fatty acids esterified at the $s n-3$ position of glycerol (Woo and Lindsay, 1984), where the major portion of the short-chain fatty acids are located. Because most of the cheeses were manufactured without pasteurization, one should not exclude a minor role played by the milk endogenous lipoprotein lipase. Nevertheless, NSLAB, especially when found at high cell numbers, may contribute to lipolysis (Gobbetti et al., 1996, 1997). The same profile of fatty acids was also found in Italian PDO ewes' milk cheeses (Di Cagno et al., 2003). High levels of ethanoic and butanoic acids were also found in hard and semihard Greek (Kondyli and Katsiari, 2001) and Spanish (Izco and Torre, 2000; Villasenor et al., 2000) ewes' milk cheeses.

\section{REFERENCES}

Albenzio, M., M. R. Corbo, S. U. Rehman, P. F. Fox, M. De Angelis, A. Corsetti, A. Sevi, and M. Gobbetti. 2001. Microbiological and biochemical characteristics of Canestrato Pugliese cheese made from raw milk, pasteurized milk or by heating the curd in hot whey. Int. J. Food Microbiol. 67:35-48.

Altschul, S. F., T. L. Madden, A. A. Schaffer, J. Zhang, Z. Zhang, W. Miller, and D. J. Lipman. 1997. Gapped BLAST and PSI-BLAST: A new generation of protein database search programs. Nucl. Acids Res. 25:3389-3402.

Andrews, A. T. 1983. Proteinases in normal bovine milk and their action on caseins. J. Dairy Res. 50:45-55.

Arora, G., F. Cormier, and B. Lee. 1995. Analysis of odour-active volatiles in Cheddar cheese headspace by multidimensional GC/ MS/sniffing. J. Agric. Food Chem. 43:748-752.

Barron, L. J. R., Y. Redeondo, C. E. Flanagan, F. J. Pérez Elortondo, M. Albisu, A. I. Nàjera, M. De Renobales, and E. Fernandez Garcìa. 2004. Comparison of the volatile composition and sensory characteristics of Spanish PDO cheeses manufactured from ewes' raw milk and animal rennet. Int. Dairy J. 15:371-382.

Battistotti, B., and C. Corradini. 1993. Cheese: Chemistry, physics and microbiology. Pages 221-243 in Italian Cheese. Vol. 2. P. F. Fox, ed. Chapman and Hall, London, UK.

Berthier, F., E. Beuvier, A. Dasen, and R. Grappin. 2001. Origin and diversity of mesophilic lactobacilli in Comtè cheese, as revealed by PCR with repetitive and species-specific primers. Int. Dairy J. 11:293-305.

Blakesley, R. W., and J. A. Boezi. 1977. A new staining technique for proteins in polyacrylamide gels using Comassie Brilliant Blue G250. Anal. Biochem. 82:580-582. 
Buffa, M., B. Guamis, C. Royo, and A. J. Trujillo. 2001. Microbiological changes throughout ripening of goat cheese made from raw, pasteurized and high-pressure-treated milk. Food Microbiol. 18:45-51.

Carbonell, M., M. Nunez, and E. Fernández-Garcìa. 2002. Evolution of the volatile components of ewe milk La Serena cheese during ripening. Correlation with flavour characteristics. Lait 82:683698.

Church, F. C., H. E. Swaisgood, D. H. Porter, and G. L. Catignani. 1983. Spectrophotometric assay using $o$-phthaldialdehyde for determination of proteolysis in milk and isolated milk proteins. J. Dairy Sci. 66:1219-1227.

Corbo, M. R., M. Albenzio, M. De Angelis, A. Sevi, and M. Gobbetti. 2001. Microbiological and biochemical properties of Canestrato Pugliese hard cheese supplemented with bifidobacteria. J. Dairy Sci. 84:551-561.

Crow, V. L. 1990. Properties of the 2,3-butanediol dehydrogenase from Lactococcus lactis subsp. lactis in relation to citrate fermentation. Appl. Environ. Microbiol. 56:1656-1662.

De Angelis, M., A. Corsetti, N. Tosti, J. Rossi, M. R. Corbo, and M. Gobbetti. 2001. Characterization of non-starter lactic acid bacteria from Italian ewe cheeses based on phenotypic, genotypic and cell wall protein analyses. Appl. Environ. Microbiol. 67:20112020.

De Angelis, M., S. Siragusa, M. Berloco, L. Caputo, L. Settanni, G. Alfonsi, M. Amerio, A. Grandi, A. Ragni, and M. Gobbetti. 2006. Selection of potential probiotic lactobacilli from pig feces to be used as additives in pelleted feeding. Res. Microbiol. [doi:10.1016/ j.resmic.2006.05.003]

De Los Reyes-Gavilán, C. G., G. K. Y. Limsowtin, P. Tailliez, L. Séchaud, and J. P. Accolas. 1992. A Lactobacillus helveticus-specific DNA probe detects restriction fragment length polymorphisms in this species. Appl. Environ. Microbiol. 58:3429-3432.

Di Cagno, R., J. Banks, L. Sheehan, P. F. Fox, E. Y. Brechany, A. Corsetti, and M. Gobbetti. 2003. Comparison of the microbiological, compositional, biochemical, volatile profile and sensory characteristics of three Italian PDO ewes' milk cheeses. Int. Dairy J. 13:961-972.

Fernàndez-Garcìa, E., P. Gaya, M. Medina, and M. Nuñez. 2003. Evolution of the volatile components of raw ewes' milk Castellano cheese: Seasonal variation. Int. Dairy J. 14:39-46.

Fox, P. F. 1989. Proteolysis during cheese manufacture and ripening. J. Dairy Sci. 72:1379-1383.

Giraffa, G., L. Rossetti, and E. Neviani. 2000. An evaluation of SELEX-based DNA purification protocols for the typing of lactic acid bacteria. J. Microbiol. Meth. 42:175-184.

Gobbetti, M., B. Folkertsma, P. F. Fox, A. Corsetti, E. Smacchi, M. De Angelis, J. Rossi, K. Kilcawley, and M. Cortini. 1999. Microbiology and biochemistry of Fossa (pit) cheese. Int. Dairy J. 9:763-773.

Gobbetti, M., P. F. Fox, E. Smacchi, L. Stepaniak, and P. Damiani. 1996. Purification and characterization of a lipase from Lactobacillus plantarum 2739. J. Food Biochem. 20:227-246.

Gobbetti, M., P. F. Fox, and L. Stepaniak. 1997. Isolation and characterization of a tributyrin esterase from Lactobacillus plantarum 2739. J. Dairy Sci. 80:3099-3106.

Goebel, B. M., and E. Stackebrandt. 1994. Cultural and phylogenetic analysis of mixed microbial populations found in natural and commercial bioleaching environments. Appl. Environ. Microbiol. 60:1614-1621.

IDF (International Dairy Federation). 1964. Determination of the protein content of processed cheeses products. Standard 25. International Dairy Federation, Brussels, Belgium.

IDF (International Dairy Federation). 1970. Determination of dry matter content in whey cheese. Standard 58. International Dairy Federation, Brussels, Belgium.

IDF (International Dairy Federation). 1988. Determination of salt content. Standard 12B. International Dairy Federation, Brussels, Belgium.

IDF (International Dairy Federation). 1989. Determination of $\mathrm{pH}$. Standard 115A. International Dairy Federation, Brussels, Belgium.
ISTAT (Istituto Nazionale di Statistica). 2001. Raccolta di latte e produzione lattiero-casearia italiana. www.istat.it/agricoltura/ agricoltura Accessed Jan. 12, 2006.

Izco, J. M., and P. Torre. 2000. Characterization of volatile flavour compounds in Roncal cheese extracted by the "purge and trap" method and analyzed by GC-MS. Food Chem. 70:409-417.

Jollivet, N., J. Chateaud, Y. Vayssier, M. Bensoussan, and J. Belin. 1994. Production of volatile compounds in model milk and cheese media by eight strains of Geotrichum candidum Link. J. Dairy Res. 61:241-248.

Jordan, K. N., and T. M. Cogan. 1999. Heat resistance of Lactobacillus spp. isolated from Cheddar cheese. Lett. Appl. Microbiol. 29:136-140.

Karahadian, C., D. B. J. Josephson, and R. C. Lindsay. 1985. Contribution of Penicillium spp. to the flavours of Brie and Camembert cheese. J. Dairy Sci. 68:1865-1877.

Kataoka, H., H. Lord, and J. Pawliszyn. 2000. Applications of solidphase microextraction in food analysis. J. Chromatogr. A. 880:35-62.

Kondyli, E., and M. C. Katsiari. 2001. Differences in lipolysis of Greek hard cheeses made from sheep's, goat's, or cow's milk. Milchwissenschaft 56:444-446.

Kuchroo, C. N., and P. F. Fox. 1982. Soluble nitrogen in Cheddar cheese: Comparison of extraction procedures. Milchwissenschaft 37:331-335.

Lane, C. N., P. F. Fox, E. M. Walsh, B. Folkertsma, and P. L. H. McSweeney. 1997. Effect of compositional and environmental factors on the growth of indigenous non-starter lactic acid bacteria in Cheddar cheese. Lait 77:561-573.

Largo Consumo. 2004. Produzione di formaggi DOP in Italia. www.largoconsumo.info Accessed Jan. 1, 2006.

Larráyoz, P., M. Addis, R. Gauch, and J. O. Bosset. 2001. Comparison of dynamic headspace and simultaneous distillation extraction techniques used for the analysis of the volatile components in three European PDO ewes' milk cheeses. Int. Dairy J. 11:911-926.

Lord, H., and J. Pawliszyn. 2000. Evolution of solid-phase microextraction technology. J. Chromatogr. A. 885:153-193.

Macedo, A. C., T. G. Tavares, and F. X. Malcata. 2004. Influence of native lactic acid bacteria on the microbiological and sensory profiles of Serra da Estrela cheese. Food Microbiol. 21:233-240.

Mannu, L., R. Comunian, and M. F. Scintu. 2000. Mesophilic lactobacilli in Fiore Sardo cheese: PCR-identification and evolution during cheese ripening. Int. Dairy J. 10:383-389.

Mariaca, R. G., E. Fernanàndez-Garcìa, A. F. Mohedano, and M. Nunez. 2001. Volatile fraction of ewe's milk semi-hard cheese manufactured with and without the addition of a cysteine proteinase. Food Sci. Technol. 212:239-246.

Martinez-Castro, I., J. Sanz, L. Amigo, M. Ramos, and P. Martin Alvarez. 1991. Volatile components of Manchego cheese. J. Dairy Res. 58:239-246.

Moio, L., and F. Addeo. 1998. Grana Padano cheese aroma. J. Dairy Res. 65:317-333.

Molimard, P., and H. E. Spinnler. 1996. Review: Compounds involved in the flavor of surface mold-ripened cheeses: Origins and properties. J. Dairy Sci. 79:169-184.

Oneca, M., A. Irigoyen, M. Ortigosa, and P. Torre. 2003. PCR and RAPD identification of Lactobacillus plantarum strains isolated from ovine milk and cheese. Geographical distribution of strains. FEMS Microbiol. Lett. 227:271-277.

Ortigosa, M., P. Torre, and M. Izco. 2001. Effect of pasteurization of ewe's milk and use of a native starter culture on the volatile components and sensory characteristics of Roncal Cheese. J. Dairy Sci. 84:1320-1330.

Pérez Elortondo, F. J., P. Aldàmiz Echobarria, M. Albisu, and Y. Barcina. 1998. Indigenous lactic acid bacteria in Idiazàbal ewes' milk cheese. Int. Dairy J. 8:725-732.

Peterson, S. D., and R. T. Marshall. 1990. Non-starter lactobacilli in Cheddar cheese: A review. J. Dairy Sci. 73:1395-1410.

Pinho, O., I. M. P. L. V. O. Ferriera, and M. A. Ferreira. 2002. Solidphase microextraction in combination with GC/MS for quantification of the major volatile free fatty acids in ewe cheese. Anal. Chem. 74:5199-5204. 
Pinho, O., I. M. P. L. V. O. Ferriera, and M. A. Ferreira. 2003a. Quantification of short-chain free fatty acids in "Terrincho" ewe cheese: Intravarietal comparison. J. Dairy Sci. 86:3102-3109.

Pinho, O., C. Pérés, and I. M. P. L. V. O. Ferriera. 2003b. Solid-phase microextraction of volatile compounds in "Terrincho" ewe cheese. Comparison of different fibers. J. Chromatogr. A. 1011:1-9.

Pinho, O., I. M. P. L. V. O. Ferriera, and M. Ferreira. 2004a. Discriminate analysis of the volatile fraction from "Terrincho" ewe cheese: Correlation with flavour characteristics. Int. Dairy J. 14:455-464.

Pinho, O., A. I. E. Pintado, A. M. P. Gomes, M. M. E. Pintado, F. X. Malacata, and I. M. P. L. V. O. Ferriera. 2004b. Interrelationship among microbiological, physicochemical and biochemical properties of Terrincho cheese, with emphasis on biogenic amines. J. Food Prot. 67:2779-2785.

Pirisi, A., C. Achilleos, D. Jaros, Y. Noel, and H. Rohm. 2000. Rheological characterisation of Protected Denomination of Origin (PDO) ewe's milk cheeses. Milchwissenschaft 55:257-259.

Poveda, J. M., M. J. Sousa, L. Cabezas, and P. L. H. McSweeney. 2002. Preliminary observations on proteolysis in Manchego cheese made with defined-strain starter culture and adjunct starter (Lactobacillus plantarum) or a commercial starter. Int. Dairy J. 13:169-178.

Preininger, M., and W. Grosch. 1994. Evaluation of key odorants of the neutral volatiles of Emmentaler cheese by the calculation of odour activity values. Lebensm. Wiss. Technol. 27:237-244.

Pripp, A., H. Shakeel-Ur-Rehman, P. L. H. McSweeney, and P. F. Fox. 1999. Multivariate statistical analysis of peptide profiles and free amino acids to evaluate effects of single-strain starters on proteolysis in miniature Cheddar-type cheeses. Int. Dairy J. 9:473-479.
Pripp, A., H. Shakeel-Ur-Rehman, P. L. H. McSweeney, T. Sørhaug, and P. F. Fox. 2000. Comparative study by multivariate statistical analysis of proteolysis in a sodium caseinate solution under cheese-like conditions caused by strains of Lactococcus. Int. Dairy J. 10:25-31.

Resmini, P., L. Pellegrino, J. Hogenboom, and M. Bertuccioli. 1988. Atti giornata di studio. Consorzio del Formaggio Parmigiano Reggiano, Reggio Emilia, Italy.

Rossetti, L., and G. Giraffa. 2005. Rapid identification of dairy lactic acid bacteria by M13-generated, RAPD-PCR fingerprint databases. J. Microbiol Meth. 63:135-144.

SAS Institute. 1985. User's Guide: Statistics, Version 5 Edition. SAS Inst., Inc., Cary, NC

Sokal, R. R., and C. D. Michener. 1958. A statistical method for evaluating systematic relationships. Univ. Kans. Sci. Bull. 38:1409-1438.

Somers, E. B., M. E. Johnson, and A. C. L. Wong. 2001. Development of amino acids and organic acids in Norvegia, influence of milk treatment and adjunct Lactobacillus. J. Dairy Sci. 84:1926-1936.

Turner, K. W., R. C. Lawrence, and J. Lelievre. 1986. A microbiological specification for milk for aseptic cheese-making. N. Z. J. Dairy Sci. Technol. 15:249-254.

Villasenor, M. J., E. Valero, J. Sanz, and I. Martìnez-Castro. 2000. Analysis of volatile components of Manchego cheese by dynamic headspace followed by automatic thermal desorption-GC-MS. Milchwissenschaft 55:378-382.

Woo, A., and R. C. Lindsay. 1984. Concentration of major free fatty acids and flavor development in Italian cheese varieties. J. Dairy Sci. 67:960-968.

Wouters, T. M., E. H. E. Ayad, J. Hugenholtz, and G. Smith. 2002. Microbes from raw milk for fermented dairy products. Int. Dairy J. 12:91-109. 